\title{
Preparation of Pt-Tl Clusters Showing New Geometries. X-ray, NMR and Luminescence Studies
}

\author{
Úrsula Belío, Sara Fuertes ${ }^{\dagger}$ and Antonio Martín*
}

Instituto de Síntesis Química y Catálisis Homogénea (ISQCH). Departamento de Química Inorgánica. Universidad de Zaragoza - CSIC. 50009 Zaragoza, Spain.

\section{${ }^{\dagger}$ ARAID Researcher}

This paper is dedicated to the memory of Professor María Pilar García Clemente

\begin{abstract}
Square planar complexes $[\mathrm{Pt}(\mathrm{CNC}) \mathrm{L}]\left(\mathrm{CNC}=\mathrm{C}, \mathrm{N}, \mathrm{C}-2,6-\mathrm{NC}_{5} \mathrm{H}_{3}\left(\mathrm{C}_{6} \mathrm{H}_{4}-2\right)_{2} ; \mathrm{L}=\right.$ tht (tetrahydrothiophene, $\mathrm{SC}_{4} \mathrm{H}_{8}, \mathbf{1}$ ), $\mathrm{L}=\mathrm{CN}^{t} \mathrm{Bu}$ (2)) react with $\mathrm{TlPF}_{6}$ in different $\mathrm{Pt} / \mathrm{Tl}$ molar ratios (3/1 in the case of $\mathbf{1}$ and $1 / 1$ in the case of 2) yielding the complexes $\left[\{\mathrm{Pt}(\mathrm{CNC})(\mathrm{tht})\}_{3} \mathrm{Tl}\right]\left(\mathrm{PF}_{6}\right)$ (3) and $\left[\mathrm{Pt}(\mathrm{CNC})\left(\mathrm{CN}^{t} \mathrm{Bu}\right) \mathrm{Tl}\right]\left(\mathrm{PF}_{6}\right)$ (4), respectively. The structures of $\mathbf{3}$ and $\mathbf{4}$ (X-ray) show the presence of $\mathrm{Pt} \rightarrow \mathrm{Tl}$ dative bonds unsupported by any bridging ligands. In complex $\mathbf{3}$, the only $\mathrm{Tl}$ centre is simultaneously bonded to three Pt atoms forming a perfect equilateral triangle, with Pt-Tl distances of 2.9088(5) A, remarkable short. Complex 4 is formed by three “ $\mathrm{Pt}(\mathrm{CNC})\left(\mathrm{CN}^{t} \mathrm{Bu}\right) \mathrm{Tl}$ ” units, disposed in a triangular fashion, linked together through $\eta^{6}$-Tl-arene interactions, and showing PtTl bonds with distances of $c a$. $3.04 \AA$. The study of these crystal structures would seem to indicate that the difference between the Pt/Tl ratio found in the complexes $\mathbf{3}$ and $\mathbf{4}$ is due to the steric requirements of the L ligand bonded to Pt. NMR studies both in solution and in the solid state shows that the Pt-Tl bond persists in solutions of $\mathbf{3}$ and $\mathbf{4}$. The UV-vis spectra of $\mathbf{3}$ and $\mathbf{4}$ in solution display the same profiles as those of $\mathbf{1}$ and $\mathbf{2}$, which may suggest a partial dissociation of the Pt-Tl bond in solution. However, by DFT calculations it was proved that in this case the formation of the $\mathrm{Pt}-\mathrm{Tl}$ dative bond does not produce the expected blue-shift in the UV-vis absorptions. The emissive
\end{abstract}


behaviour of 1-4 in solid state and frozen solutions is also studied and included in this work.

\section{Introduction}

Metallophilic interactions between closed or pseudo closed shell transition metals $\left(d^{10}, d^{8}, d^{10} s^{2}\right)$ have been used as a tool in the field of crystal or molecular engineering, linking different subassemblies. A wide array of structural types has been reported for complexes with this kind of interaction, from simple linear bimetallic compounds to infinite one-dimensional chains. ${ }^{1-17}$ In many cases, complexes containing these metalmetal bonds have also been shown to exhibit photophysical and photochemical properties, such as luminescence, attributable to the existence of the metallophilic interactions. ${ }^{6,16,18-42}$

$\mathrm{Tl}(\mathrm{I})$ is a fairly representative acceptor in this sort of heteropolynuclear clusters. It shows a $\mathrm{d}^{10} \mathrm{~s}^{2}$ electron configuration and is a typical case of "inert pair" species. ${ }^{5,} 43$ Examples of the following donor-Tl(I) couples are known: $\operatorname{Ru}(0)\left(\mathrm{d}^{8}\right) \rightarrow \mathrm{Tl}(\mathrm{I}),{ }^{44}$ $\mathrm{Rh}(\mathrm{I})\left(\mathrm{d}^{8}\right) \rightarrow \mathrm{Tl}(\mathrm{I}),{ }^{45,}{ }^{46} \mathrm{Ir}(\mathrm{I})\left(\mathrm{d}^{8}\right) \rightarrow \mathrm{Tl}(\mathrm{I}),{ }^{47,}{ }^{48} \mathrm{Pt}(\mathrm{II})\left(\mathrm{d}^{8}\right) \rightarrow \operatorname{Tl}(\mathrm{I}),{ }^{5,},{ }^{40,66} \mathrm{Pt}(0)\left(\mathrm{d}^{10}\right) \rightarrow \mathrm{Tl}(\mathrm{I}),{ }^{67-}$ ${ }^{70} \mathrm{Pd}(\mathrm{II})\left(\mathrm{d}^{8}\right) \rightarrow \mathrm{Tl}(\mathrm{I})^{71,72}$ and $\mathrm{Au}(\mathrm{I})\left(\mathrm{d}^{10}\right) \rightarrow \mathrm{Tl}(\mathrm{I}),{ }^{43,}{ }^{73-83} \mathrm{Pt}(\mathrm{II})$ and $\mathrm{Au}(\mathrm{I})$ being the two main donor centres. With regard to $\mathrm{Pt}(\mathrm{II}) \rightarrow \mathrm{Tl}(\mathrm{I})$ heteropolynuclear clusters specifically, several structural configurations have been reported, dinuclear PtTl discrete examples, ${ }^{10}$, 50-53 trinuclear $\mathrm{PtTl}_{2}{ }^{49,54-56}$ or $\mathrm{Pt}_{2} \mathrm{Tl}$ "sandwiches", 5, 57-59 tetranuclear “paired" $(\mathrm{PtTl})_{2},{ }^{10}$, 60-64 or infinite networks. 5, 59, 61, 64-66 Often Pt-Tl bonds are supported by bridging ligands between the two metallic centres, and/or the thallium atoms bear additional ligands.

Furthermore, the use of cyclometallated planar aromatic $C^{\wedge} N$ ligands on the coordination sphere of the platinum (II) has been one of the lines of research undertaken in our laboratory. ${ }^{2}$, 3, 16, 42, 84 These planar ligands confer two interesting characteristics to the complex. Firstly, they are strong field ligands that cause the $\mathrm{d}_{\mathrm{z}}{ }^{2}$ platinum orbital to raise its energy and favour the formation of stronger $\mathrm{Pt} \rightarrow \mathrm{M}$ dative bonds. ${ }^{85,}{ }^{86}$ In addition, the presence of aromatic rings coplanar with the Pt square plane allows for the presence of intermolecular $\pi \cdots \pi$ interactions between the planar ligands, establishing different types of supramolecular arrangements. ${ }^{2,}$ 6, 16, 17, 42, 87, 88 Along with hydrogen 
bonding, this kind of $\pi \cdots \pi$ stacking is one of the most important secondary interactions $^{89-94}$ in the field of modern supramolecular chemistry, ${ }^{95-98}$ playing an important role in processes such as molecular self-assembly and self-recognition of aromatic entities in the crystal state, and also having an important role in the luminescent properties of some compounds. ${ }^{84}$

In this paper we report the use of Pt precursors containing the tridentate cyclometallated 2,6-diphenylpyridinate (CNC) ligand. Its use has allowed to prepare and characterize two clusters containing unsupported $\mathrm{Pt}(\mathrm{II}) \rightarrow \mathrm{Tl}(\mathrm{I})$ bonds with unprecedented geometries. Their photophysical properties have also been studied.

Some of the results contained in this paper have been previously reported in the form of a short communication. ${ }^{99}$

\section{Results and discussion}

Syntheses of $[\mathrm{Pt}(\mathrm{CNC}) \mathrm{L}]\left(\mathrm{L}=\right.$ tht (tetrahydrothiophene, $\left.\left.\mathrm{SC}_{4} \mathrm{H}_{8}, 1\right), \mathrm{L}=\mathrm{CN}^{t} \mathrm{Bu}(2)\right)$

The preparation and structural characterization of the starting material $[\mathrm{Pt}(\mathrm{CNC})(\mathrm{dmso})]$ (dmso = dimethyl sulfoxide) have already been reported. ${ }^{100}$ Nevertheless, we have modified the synthetic route since we experienced some problems following the reported method of preparation (see Experimental). Complexes $[\mathrm{Pt}(\mathrm{CNC}) \mathrm{L}] \quad\left(\mathrm{CNC}=\mathrm{C}, \mathrm{N}, \mathrm{C}-2,6-\mathrm{NC}_{5} \mathrm{H}_{3}\left(\mathrm{C}_{6} \mathrm{H}_{4}-2\right)_{2}\right.$ (see Scheme 1$) ; \mathrm{L}=$ tht (tetrahydrothiophene, $\mathrm{SC}_{4} \mathrm{H}_{8}, 1$ ), $\mathrm{L}=\mathrm{CN}^{t} \mathrm{Bu}(2)$ ) have been prepared by replacing the dimethyl sulfoxide ligand in the precursor $[\mathrm{Pt}(\mathrm{CNC})(\mathrm{dmso})]$ with the corresponding $\mathrm{L}$ (see Experimental for details). This procedure has already been used in the synthesis of similar $[\mathrm{Pt}(\mathrm{CNC}) \mathrm{L}]^{101-104},[\mathrm{Pt}(\mathrm{CNC}) \mathrm{X}]^{-101}$ or $[\mathrm{Pt}(\mathrm{CNC}) \mathrm{L}]^{+104}$ complexes.

Both the IR and ${ }^{1} \mathrm{H}$ NMR spectra of complexes $\mathbf{1}$ and $\mathbf{2}$ have the corresponding signals attributable to the ligands present in the complexes, with the expected relative intensity (see Experimental). Furthermore the crystal structure of $\mathbf{1}$ has been determined by X-ray diffraction. Figure 1 shows a view of the complex and Table 1 lists a selection of relevant bond distances and angles. As expected, the crystal structure of $\mathbf{1}$ shows a square planar coordination for the platinum, with structural parameters for the "Pt(CNC)" fragment that are very similar to those reported for platinum complexes containing this ${ }^{100}$ or similar tridentate CNC ligands. ${ }^{88}$ The Pt-S distance is also similar 
to that found in the similar complex $\left[\mathrm{Pt}\left(2,6\right.\right.$-diphenylisonicotinate)(tht)]. ${ }^{88}$ No intermolecular $\pi \cdots \pi$ interactions between the aromatic rings of the CNC plane ligands are present in $\mathbf{1}$.

\section{Reactions of 1 and 2 with TIPF $_{6}$.}

Complexes $\mathbf{1}$ and $\mathbf{2}$ are suitable precursors for the synthesis of new clusters containing $\mathrm{Pt}(\mathrm{II}) \rightarrow \mathrm{Tl}(\mathrm{I})$ bonds. We have tested the reactions of $\mathbf{1}$ and $\mathbf{2}$ toward $\mathrm{TlPF}_{6}$ in dichloromethane in different Pt/Tl molar ratios. Both 1 and 2 always react in a fixed $\mathrm{Pt} / \mathrm{Tl}$ proportion, 3/1 in the case of $\mathbf{1}$ and $1 / 1$ in the case of 2 . If other proportions are used, the corresponding unreacted products are recovered.

Thus, the reaction of 3 equivalents of 1 with 1 equivalent of $\mathrm{TlPF}_{6}$, results, after work up of the solution, in a red solid whose spectroscopic and analytical data correspond to the formula $\left[\{\mathrm{Pt}(\mathrm{CNC})(\mathrm{tht})\}_{3} \mathrm{Tl}\right]\left(\mathrm{PF}_{6}\right)$ (3). Similarly, the reaction of 1 equivalent of 2 with 1 equivalent of $\mathrm{TPF}_{6}$, allows to obtain an orange solid whose spectroscopic and analytical data correspond to the formula $\left[\mathrm{Pt}(\mathrm{CNC})\left(\mathrm{CN}^{t} \mathrm{Bu}\right) \mathrm{Tl}\right]\left(\mathrm{PF}_{6}\right)$ (4) (see Scheme 1).

The complete understanding of the solid state structures of these complexes has been achieved through single crystal X-ray studies of both 3 and $\mathbf{4}$. Figures 2 and 3 show views of the corresponding complexes and Tables 2 and 3 list a selection of relevant bond distances and angles.

Complex 3 is a tetranuclear $\mathrm{Pt}_{3} \mathrm{Tl}$ cluster in which the $\mathrm{Tl}(\mathrm{I})$ centre lies on a 6-fold axis and thus the three Pt atoms form a perfect equilateral triangle with the thallium atom in the centre, the Pt-Tl-Pt angles being exactly $120^{\circ}$. Due to the molecular symmetry, the three Pt-Tl distances are the same, 2.9088(5) $\AA$. To the best of our knowledge, this value is the shortest reported so far for a $\mathrm{Pt}(\mathrm{II})-\mathrm{Tl}(\mathrm{I})$ bond unassisted by any bridging ligand or by pairing $(\mathrm{PtTl})_{2}$ metallocycle systems. The trigonal environment of the $\mathrm{Tl}$ centre seems to indicate the steric inactivity of its lone $6 \mathrm{~s}^{2}$ electron pair, that is usually stereoactive, ${ }^{105}$ which is a feature that has been previously observed in some $\mathrm{M} \rightarrow \mathrm{Tl}(\mathrm{I})$ clusters. ${ }^{5,43}$ Some $\mathrm{M}_{3} \mathrm{Tl}(\mathrm{III})$ complexes with a symmetrical trigonal environment for the thallium(III) centre are known and they involve low valent metal carbonyl complexes with general formulae $\left[\left\{\mathrm{M}(\mathrm{CO})_{\mathrm{x}}\left(\eta-\mathrm{C}_{5} \mathrm{H}_{5}\right)\right\}_{3}\left(\mu_{3}-\mathrm{Tl}\right)\right\} \quad \mathrm{x}=3$; $\left.. \mathrm{M}=\mathrm{Cr}, \mathrm{Mo}^{106} \cdot \mathrm{x}=2, \mathrm{M}=\mathrm{Ru}^{44}, \mathrm{Fe}^{107}\right)$ or $\left[\left\{\mathrm{M}(\mathrm{CO})_{4}\right\}_{3}\left(\mu_{3}-\mathrm{Tl}\right)\right\}^{\mathrm{n}-}\left(\mathrm{n}=0 ; . \mathrm{M}=\mathrm{Cr}^{107} \cdot \mathrm{n}=\right.$ 3, $\mathrm{M}=\mathrm{Fe}^{107}$ ). However, 3 is the first $\mathrm{Tl}(\mathrm{I})$ complex in which this striking trigonal 
environment is found. As far as we know, there are only another three reports of clusters in which three donor metal atoms are simultaneously bonded to a $\mathrm{Tl}(\mathrm{I})$ centre and their geometry clearly departs from a regular trigonal disposition. One is $\left[\left\{\mathrm{Pt}(\mathrm{pda})\left(\mathrm{NHCO}^{t} \mathrm{Bu}\right)_{2}\right\}_{4} \mathrm{Tl}_{4}\right]\left[\mathrm{Pt}(\mathrm{CN})_{4}\right]_{2}$ (pda $=1,2$-propyldiamine), ${ }^{66}$ in which infinite “ $\left\{\mathrm{Pt}(\mathrm{pda})\left(\mathrm{NHCO}^{t} \mathrm{Bu}\right)_{2}\right\} \mathrm{Tl}$ ”chains are linked via half of the $\mathrm{Tl}$ with “Pt(CN)$)_{4}$ ” units acting as connectors, resulting in a three-dimensional network. Nevertheless, in this case, the environment of the $\mathrm{Tl}$ connected to three platinum atoms is not symmetric, with longer Pt-Tl bond distances (range 2.986-3.250 $\AA$ ) and $\mathrm{NHCO}^{t} \mathrm{Bu}$ ligands bridging Pt and Tl. The other two cases present a family of six gold(I) complexes: $\left\{\mathrm{NBu}_{4}\left[\mathrm{Tl}_{2}\left\{\mathrm{Au}\left(\mathrm{C}_{6} \mathrm{Cl}_{5}\right)_{2}\right\}\left\{\mu-\mathrm{Au}\left(\mathrm{C}_{6} \mathrm{Cl}_{5}\right)_{2}\right\}_{2}\right]\right\}_{\mathrm{n}},{ }^{43} \quad\left\{\mathrm{NBu}_{4}\left[\mathrm{Tl}\left\{\mathrm{Au}\left(3,5-\mathrm{C}_{6} \mathrm{Cl}_{2} \mathrm{~F}_{3}\right)_{2}\right\}_{2}\right]\right\}_{\mathrm{n}},{ }^{43}$ $\left\{\mathrm{NBu}_{4}\left[\mathrm{Tl}\left\{\mathrm{Au}\left(\mathrm{C}_{6} \mathrm{Cl}_{5}\right)_{2}\right\}\left\{\mathrm{Au}\left(3,5-\mathrm{C}_{6} \mathrm{Cl}_{2} \mathrm{~F}_{3}\right)_{2}\right\}\right]\right\}_{\mathrm{n}}{ }^{43}$

$\left\{\mathrm{NBu}_{4}\left[\mathrm{Tl}_{2}\left\{\mathrm{Au}\left(2 \mathrm{C}_{6} \mathrm{~F}_{4} \mathrm{Br}\right)_{2}\right\}_{3}\right]\right\}_{\mathrm{n}},{ }^{81}\left\{\mathrm{NBu}_{4}\left[\mathrm{Tl}_{2}\left\{\mathrm{Au}\left(2-\mathrm{C}_{6} \mathrm{~F}_{4} \mathrm{I}\right)_{2}\right\}_{3}\right]\right\}_{\mathrm{n}},{ }^{81}$ and $\left\{\mathrm{NBu}_{4}[\mathrm{Tl}\{\mathrm{Au}(2-\right.$ $\left.\left.\left.\left.\mathrm{C}_{6} \mathrm{~F}_{4} \mathrm{Br}\right)_{2}\right\}_{2}\right]\right\}_{\mathrm{n}}{ }^{81}$ These complexes are basically prepared by the incorporation of [AuR $]^{-}$ to $\left[\mathrm{AuTlR}_{2}\right]_{\mathrm{n}}\left(\mathrm{R}=\mathrm{C}_{6} \mathrm{Cl}_{5}, 3,5-\mathrm{C}_{6} \mathrm{Cl}_{2} \mathrm{~F}_{3}, 2-\mathrm{C}_{6} \mathrm{~F}_{4} \mathrm{Br}, 2-\mathrm{C}_{6} \mathrm{~F}_{4} \mathrm{I}\right)$ chains and the formation of a third $\mathrm{Au}-\mathrm{Tl}$ bond. The $\mathrm{Au}-\mathrm{Tl}$ distances range from 2.935 to $3.466 \AA$ and the environments of the $\mathrm{Tl}$ atoms are planar, but not symmetrical, being best described as distorted T-shaped.

The three "Pt(CNC)(tht)" units in $\mathbf{3}$ are disposed in such a way that the best square Pt planes form an equilateral triangle. Each of the three tht ligands is pointing in the same direction. The Pt-Tl lines are perpendicular to their respective Pt plane, which is an arrangement that is usually found in complexes showing $\mathrm{Pt} \rightarrow \mathrm{M}$ dative bonds, and which maximizes the overlapping of the full $5 d_{\mathrm{z}} 2 \mathrm{Pt}(\mathrm{II})$ orbital and the empty orbitals of the acidic metal centre. ${ }^{5,10,53,108}$ It is more likely that the disposition adopted by the three "Pt(CNC)(tht)" was the optimal (and perhaps the only possible) one to accommodate the these three bulky groups. The tht rings are bent away from the interior of the $\mathrm{Pt}_{3} \mathrm{Tl}$ core thus minimizing the repulsion with the CNC ligand of the adjacent unit. Moreover, the plane of the CNC ligands is distorted in such a way that their pyridine rings, the closest to the tht of the adjacent unit, are moved back from the best Pt square plane, while the two phenylene rings, which have less steric hindrance, move slightly inside the centre of the core. It its noteworthy that despite the apparent steric hindrance, the Pt-Tl distances are short for this kind of complexes.

Complex 4 (see Figure 3) is formed by three “Pt(CNC)(CN $\left.{ }^{t} \mathrm{Bu}\right) \mathrm{Tl}$ ” units, disposed in a triangular fashion and linked together through $\eta^{6}$-Tl-arene interactions established 
with one of the phenylene rings of a neighbouring moiety. Each of the three units shows a direct Pt-Tl bond unassisted by any bridging ligand. The intermetallic bond distances are $\operatorname{Pt}(1)-\mathrm{Tl}(1)$ 3.0143(3) $\AA, \operatorname{Pt}(2)-\mathrm{Tl}(2)$ 3.0488(3) $\AA$ and $\operatorname{Pt}(3)-\mathrm{Tl}(3)$ 3.0460(3) $\AA$, which are in the short range of this kind of interactions. The Pt-Tl lines are tilted 16.3(1) ${ }^{\circ}(\operatorname{Pt}(1)), 20.6(1)^{\circ}(\operatorname{Pt}(2))$ and $22.2(1)^{\circ}(\operatorname{Pt}(3))$ with respect to the perpendicular to the best Pt square planes. This deviation could be caused by the triangular disposition of the complexes to establish the $\eta^{6}$-Tl-arene interactions. Complexes in which the Pt-Tl moieties are ordered in pairs through additional bonds or interactions of the thallium centre to a neighbour unit are known, ${ }^{10,50,60-64}$ but as far as we know, no other examples of the triangular "trimeric" disposition of Pt-Tl units found in $\mathbf{4}$ have been previously reported.

The $\eta^{6}$-Tl-arene interactions found in $\mathbf{4}$ are fairly symmetric. The maximum and minimum Tl-C distances are 3.361(7)-3.152(7) $\AA$ for Tl(1), 3.371(7)-3.223(6) $\AA$ for $\mathrm{Tl}(2)$ and 3.450(6)-3.221(7) $\AA$ for $\mathrm{Tl}(3)$. The distance of each thallium centre to the calculated centroids of these rings is 2.959, 2.978 and $3.021 \AA$ respectively, and the PtTl-centroid angles are $140.7(1)^{\circ}$ for $\mathrm{Tl}(1), 145.2(1)^{\circ}$ for $\mathrm{Tl}(2)$ and $144.7(1)^{\circ}$ for $\mathrm{Tl}(3)$, which seems to indicate, in this case, the stereoactivity of the $\mathrm{Tl}(\mathrm{I})$ lone $6 \mathrm{~s}^{2}$ electron pair. ${ }^{105} \eta^{6}$-Tl-arene interactions do not seem to be very frequent and a search in the CCDC structural database (version 5.35, updated November 2013) revealed just a couple of dozens of reported structures containing this feature. ${ }^{52,109-119}$

As in 3, the three Pt planes in $\mathbf{4}$ form an almost perfect equilateral triangle, with dihedral angles of $c a$. $60^{\circ}$. Nevertheless, the disposition of the planes is different from that observed for 3 . In 4 , the $\mathrm{CN}^{t} \mathrm{Bu}$ ligands are pointing outwards from the triangular core formed by the Pt planes, two in one direction and the third in the opposite direction. The triangular "cavity” formed by the Pt planes in much smaller in $\mathbf{3}$ than in $\mathbf{4}$ (see Figure 4). An idea of this is given by the separation of the Pt atoms which is 5.038(1) $\AA$ for 3 and ca. 7.674(1) $\AA$ for 4. Another indication that the triangular disposition of the Pt planes is less sterically stressed in $\mathbf{4}$ than in $\mathbf{3}$ is the observation that the CNC planes are much less distorted in the first complex than in the second.

All these observations seem to point to the difference between the $\mathrm{Pt} / \mathrm{Tl}$ ratio found in the complexes $\mathbf{3}$ and $\mathbf{4}$ being due to the steric requirements of the L ligand bonded to Pt. Thus, in $\mathbf{3}$ the tht ligand seems to be very flexible and able to adopt a disposition in which its carbon atoms move away from the crowded core formed by the 
three Pt planes. As a result of this, the cavity formed can only accommodate one Tl(I) cation that fits snugly between the three Pt atoms and bonds all three. On the other hand, the $\mathrm{CN}^{t} \mathrm{Bu}$ ligands in $\mathbf{4}$ are less flexible due to the $\mathrm{CN}$ triple bond and their compulsory linear disposition, and the relatively bulky $t$-butyl ends prevent the “Pt(CNC)(CN $\left.{ }^{t} \mathrm{Bu}\right)$ ” units from approaching each other more. Consequently, the inner cavity is big enough for three $\mathrm{Tl}(\mathrm{I})$ cations and three different individual Pt-Tl bonds to exist, and even allows the relative approximation of two $\mathrm{PF}_{6}{ }^{-}$anions whose fluorine atoms make contact with the $\mathrm{Tl}$ centres.

The crystal structures of $\mathbf{3}$ and $\mathbf{4}$ have also revealed the presence of $\pi \cdots \pi$ intermolecular interactions established between the aromatic rings of the CNC ligand of adjacent units, which lie in parallel planes with interplanar distances of ca.3.4 $\AA$ (see Figure S1, Supplementary Information). As mentioned previously, these $\pi \cdots \pi$ interactions have been found for complexes containing planar cyclometallated ligands. ${ }^{2}$, 6, 16, 17, 42, 87, 88, 103, 120 Thus, in the case of $\mathbf{3}$, the final result is a three-dimensional network linked by $\pi \cdots \pi$ interactions (see Figure S1a), whereas for $\mathbf{4}$ a two-dimensional "sheet" of triangles is formed (see Figure S1b).

\section{NMR studies}

The ${ }^{1} \mathrm{H}$ NMR spectra of $\mathbf{1}$ and $\mathbf{2}$ in $\mathrm{CD}_{2} \mathrm{Cl}_{2}$ show the corresponding signals for the $\mathrm{CNC}$ and tht or $\mathrm{CN}^{t} \mathrm{Bu}$ ligands, respectively (see Experimental). On the NMR time scale, both halves of the CNC ligands are equivalent, and thus six signals are observed for this ligand. In the case of $\mathbf{1}$, the two halves of the tht ligands are also equivalent and two signals are present. For 2 , all the methyl groups of the $\mathrm{CN}^{t} \mathrm{Bu}$ ligand are equivalent, giving rise to one singlet.

The ${ }^{1} \mathrm{H}$ NMR spectrum of $\mathbf{3}$ is very similar to that of its precursor $\mathbf{1}$. The most significant shift of the signals observed in the spectrum of $\mathbf{3}$ is that corresponding to the ortho phenyl proton $\left(\mathrm{H}^{2}\right)$ of the $\mathrm{CNC}$ ligand, which moves upfield $0.66 \mathrm{ppm}$ with respect to $\mathbf{1}$. The ${ }^{1} \mathrm{H}$ NMR spectra of $\mathbf{2}$ and $\mathbf{4}$ display almost identical profiles and thus there is no evidence of the persistence in solution of the $\eta^{6}$-Tl-arene interactions found in the crystals of 4 .

In order to establish if $\mathrm{Pt}(\mathrm{II}) \rightarrow \mathrm{Tl}(\mathrm{I})$ dative bonds remain in solution, we have conducted several ${ }^{195} \mathrm{Pt}\left\{{ }^{1} \mathrm{H}\right\}$ NMR experiments (see Figure 5). In $\mathrm{CD}_{2} \mathrm{Cl}_{2}$ solution at room temperature, compound $\mathbf{1}$ shows a slightly structured ${ }^{195} \mathrm{Pt}$ resonance at -3914 
ppm, due to the quadrupolar nature of ${ }^{14} \mathrm{~N}$ of the CNC ligand. ${ }^{121}$ However, the spectrum of $\mathbf{3}$ in the same conditions does not show any signal, probably because this cluster dissociates in solution giving rise to a mixture of different $\mathrm{Pt} / \mathrm{Tl}$ species which are in equilibrium on the ${ }^{195} \mathrm{Pt}$ NMR time scale. However, upon the addition of excess $\mathrm{TlPF}_{6}$, a ${ }^{195} \mathrm{Pt}$ NMR signal is observed at $-3157 \mathrm{ppm}$. The downfield shift with respect to the signal in the starting material $\mathbf{1}$ is $757 \mathrm{ppm}$, consistent with the formation of $\mathrm{Pt} \rightarrow \mathrm{M}$ dative bonds in solution. This downfield shift is caused by the decrease of electron density around the Pt centre upon coordination to $\mathrm{M}^{+}$. 4, 15-17, 122, 123 Exactly this same dissociation process at ${ }^{195} \mathrm{Pt}$ NMR time scale was formerly observed in solutions of compounds containing $\mathrm{Pt} \rightarrow \mathrm{Cd}^{4}$ and $\mathrm{Pt} \rightarrow \mathrm{Ag}^{15,123}$ dative bonds.

Variable temperature ${ }^{195} \mathrm{Pt}\left\{{ }^{1} \mathrm{H}\right\}$ NMR experiments were performed on a $\mathrm{CD}_{2} \mathrm{Cl}_{2}$ solution of 3 with $\mathrm{TlPF}_{6}$ in excess (see Figure $5 \mathrm{a}$ ). At $193 \mathrm{~K}$, the spectrum shows a doublet at $-3100 \mathrm{ppm}$ due to Pt-Tl coupling $\left({ }^{1} J_{\mathrm{Pt}-\mathrm{Tl}}=8.9 \mathrm{kHz}\right)$ which collapse to a broad signal at $243 \mathrm{~K}$. This coupling constant value is similar to that observed in reported compounds with $\mathrm{Pt}(\mathrm{II}) \rightarrow \mathrm{Tl}(\mathrm{I})$ dative bonds. ${ }^{50,51,124}$ The separate ${ }^{1} \mathrm{~J}_{195 \mathrm{Pt}-203 \mathrm{Tl}},{ }^{1} \mathrm{~J}_{195 \mathrm{Pt}-205 \mathrm{Tl}}$ coupling constants cannot be measured due to the broadness of the signals. Furthermore, at $193 \mathrm{~K}$ the ${ }^{195} \mathrm{Pt}$ NMR spectrum of $\mathbf{1}$ barely changes displaying a singlet at $-3901 \mathrm{ppm}$ (see Figure 5b). Both ${ }^{195} \mathrm{Pt}$ resonances appear downfield shifted with respect to those at $\mathrm{RT}$ and the difference between them increases up to $801 \mathrm{ppm}$. It is worth noting that the sample with excess of $\mathrm{TlPF}_{6}$ showed identical ${ }^{1} \mathrm{H}$ NMR spectrum to that of compound 3.

In order to confirm that the ${ }^{195} \mathrm{Pt}$ NMR spectra obtained in solution reflect the structure revealed by the X-ray diffraction studies, solid state ${ }^{195} \mathrm{Pt}$ NMR spectra of $\mathbf{1}$ and 3 were measured. For compound 1, spectra were registered at spinning speeds of 8 and $12 \mathrm{KHz}$ (see Figure S2, Supplementary Information). The isotropic chemical shift 3816 ppm agrees well with the solution ${ }^{195} \mathrm{Pt}$ NMR value at $193 \mathrm{~K}$ (-3901 ppm) (see Figure 6).

Compound 3 was studied at 5, 8 and $12 \mathrm{kHz}$ spinning speeds (see Figure S3, Supplementary Information). At $5 \mathrm{kHz}$, the broad spectrum affords a rather low resolution, however, at 8 and $12 \mathrm{kHz}$ the ${ }^{195} \mathrm{Pt}$ NMR spectra displayed a better resolved pattern with clear evidence of splitting due to the Pt-Tl coupling. The ${ }^{195} \mathrm{Pt}$ signal appears as a doublet centered at -3088 ppm with a coupling constant of $9.0 \mathrm{kHz}$, which 
is in close agreement with the solution ${ }^{195} \mathrm{Pt}$ NMR data at $193 \mathrm{~K}\left(-3100 \mathrm{ppm}\right.$ and ${ }^{1} J_{\mathrm{Pt}-\mathrm{Tl}}$ $=8.9 \mathrm{kHz})$.

The remarkable downfield shifts (> $750 \mathrm{ppm}$ ) in relation to its precursor $\mathbf{1}$, and the extraordinarily high value of the $\mathrm{Pt}(\mathrm{II})-\mathrm{Tl}(\mathrm{I})$ coupling constant $(8.9 \mathrm{kHz})$ are indicative of a fairly strong $\mathrm{Pt} \rightarrow \mathrm{Tl}$ dative bond in solution for 3. Furthermore, from the ${ }^{195} \mathrm{Pt}$ resonances obtained either at RT or low temperature for $\mathbf{3}$ it is clear that only one $\mathrm{Pt} / \mathrm{Tl}$ species is present and that it matches with the solid state structure perfectly, as shown by the solid ${ }^{195} \mathrm{Pt}$ NMR spectra. Hence, the excess of thallium in the media just prevents the dissociation process and the only species formed is the tetranuclear one.

Likewise, the same ${ }^{195} \mathrm{Pt}$ NMR studies were performed on 2 and $\mathbf{4}$. Compound $\mathbf{4}$ shows a very broad and weak ${ }^{195} \mathrm{Pt}$ resonance at $-3795 \mathrm{ppm}$ in $\mathrm{CD}_{2} \mathrm{Cl}_{2}$ solution at room temperature. Since the signal is very weak, even after 30000 acquisition scans, the ${ }^{195} \mathrm{Pt}$ NMR spectrum was repeated adding an excess of $\mathrm{TlPF}_{6}$. In this case, a stronger ${ }^{195} \mathrm{Pt}$ signal was recorded in the same spectral region (-3766 ppm), as seen in Figure S4 (Supplementary Information). Since the ${ }^{1} \mathrm{H}$ NMR spectrum of this sample is identical to that recorded for 4; it was used in the following experiments. Thus, when the ${ }^{195} \mathrm{Pt}$ resonance of 4 is compared with that obtained in compound 2 (-4051 ppm), a downfield shift of 285 ppm is observed (see Figure 7). This is in line with observations for $\mathbf{1}$ and $\mathbf{3}$ and also with previously reported results. ${ }^{4,15-17,122,123}$ Following the same procedure, the ${ }^{195} \mathrm{Pt}\left\{{ }^{1} \mathrm{H}\right\}$ NMR spectra of 2 and $\mathbf{4}$ were recorded in a solution of $\mathrm{CD}_{2} \mathrm{Cl}_{2}$ at $193 \mathrm{~K}$. The spectrum of 2 displays a sharp singlet at $-4076 \mathrm{ppm}$, whereas that corresponding to 4 does not show any signal at all. The experiment was repeated at $263 \mathrm{~K}$ and a much weaker and broader signal appears downfield shifted (-3675 ppm) compared to that observed at room temperature (see Figure 7). This behaviour is similar to that described for compound 3 (see above). However, unlike compound 3, no Pt-Tl coupling was observed in the case of 4 .

In an attempt to identify and confirm the ${ }^{195} \mathrm{Pt}$ resonances, solid state NMR experiments were carried out on compounds $\mathbf{2}$ and $\mathbf{4}$. The spectra of $\mathbf{2}$ were recorded at spinning speeds of 5, 8 and $12 \mathrm{kHz}$ (see Figure S5, Supplementary Information). The isotropic chemical shift $-4020 \mathrm{ppm}$ agrees well with the solution ${ }^{195} \mathrm{Pt} \mathrm{NMR}$ value at $193 \mathrm{~K}$ (-4076 ppm). Compound 4 was also studied at the same spinning speeds but a well resolved pattern was not obtained at any spinning rate. Nevertheless, the moderate downfield shifts (> $280 \mathrm{ppm}$ ) in relation to its precursor (2) observed in $\mathrm{CD}_{2} \mathrm{Cl}_{2}$ at room 
and low $(263 \mathrm{~K}$ ) temperature is in agreement with the existence of $\mathrm{Pt} \rightarrow \mathrm{Tl}$ dative bonds in solution for compound $\mathbf{4}$, but ones that are significantly weaker than those observed in compound 3.

\section{Photophysical properties}

Absorption Spectra and Theoretical Calculations. UV-vis spectra data of compounds 1-4 in solution are summarized in Table S1 (see Supplementary Information). In diluted solution $\left(10^{-5} \mathrm{M}\right)$, compounds 1 and 2 display structured bands at $330-350 \mathrm{~nm}\left(\varepsilon>10^{4} \mathrm{M}^{-1} \mathrm{~cm}^{-1}\right)$ that appear to be fairly insensitive to the ancillary ligand and the solvent polarity (see Figure S6 and S7, Supplementary Information). These are typical of metal-perturbed ligand centered transitions ( $\left.{ }^{1} \mathrm{IL}, \mathrm{CNC}\right) .{ }^{17,} 88,93,101$, 104, 125 In addition, they all show weak shoulder bands at lower energies: 410-440 nm ( $\varepsilon$ $\sim 10^{3} \mathrm{M}^{-1} \mathrm{~cm}^{-1}$ ) as shown in the Inset of Figure S6. On the basis of previous work on closely related derivatives $[\mathrm{Pt}($ Ethyl-2,6-diphenylisonicotinate $\left.)(\mathrm{L})] ; \mathrm{L}=\mathrm{tht}, \mathrm{CN}^{\mathrm{t} B u}\right]{ }^{88}$ and literature reports,. ${ }^{17,}$ 88, 93, 101, 104, 125, 126 these weak shoulder absorptions are attributed to a ${ }^{1} \mathrm{MLCT}\left[5 \mathrm{~d}(\mathrm{Pt}) \rightarrow \pi^{*}(\mathrm{CNC})\right]$ transition. Compounds $\mathbf{3}$ and $\mathbf{4}$ exhibit very similar absorption profiles to those of the precursor. Unlike other reported compounds containing $\mathrm{Pt} \rightarrow \mathrm{M}$ dative bonds, ${ }^{1,2,16}$ the low energy absorption bands in $\mathbf{3}$ and $\mathbf{4}$ do not display any significant blue shift compared to those of $\mathbf{1}$ and 2, respectively (Table S1, Supplementary Information). A very similar behaviour was observed in the heterotrinuclear clusters $\left[\{(\text { Ethyl-2,6-diphenylisonicotinate }) \operatorname{Pt}(\operatorname{dmpyz})\}_{2} \mathrm{M}\right]^{+}(\mathrm{M}=\mathrm{Cu}$, Ag). ${ }^{17}$ This blue shift is normally attributed to the existence of dative $\mathrm{Pt} \rightarrow \mathrm{M}$ bonds which increases the electrophilicity of the Pt centre and lowers the energy of the HOMO, resulting in an increase of the energy gap of the ${ }^{1}$ MLCT transition.

Solid state diffuse reflectance spectra of 1-4 are depicted in Figure 8. The mononuclear complexes $\mathbf{1}$ and $\mathbf{2}$ exhibit identical profiles to those of the solution. In compounds 3 and 4 the low-energy bands (432 nm (3); 420 and $443 \mathrm{~nm}$ (4)), also present in $\mathbf{1}$ and $\mathbf{2}$ (solid state) and in solution, are greatly enhanced when compared to their corresponding precursors. These bands were attributed to ${ }^{1}$ MLCT $\left[5 \mathrm{~d}(\mathrm{Pt}) \rightarrow \pi^{*}(\mathrm{CNC})\right]$ transitions but in the case of $\mathbf{3}$ and $\mathbf{4}$ they are clearly perturbed by the existence of Pt-Tl bonds, 5, 51, 61 especially in 3, that displays rather short Pt-Tl separations (2.9086(5) Å). There are also weaker shoulder bands at ca $540 \mathrm{~nm}$ possibly due to $\pi \cdots \pi$ interactions between the CNC fragments, as shown in the X-ray structures 
(see Figure S1, Supplementary Information). The absence of $\pi \cdots \pi$ contacts between the CNC ligands in crystal structure of $\mathbf{1}$ would be in agreement with this assignment.

To shed some light on the nature of low-energy transitions, time-dependent density functional theory (TD-DFT) calculations were carried out using the hybrid density functional M06 for 2 and 4' (4' is a model complex derived from one of the units "Pt(CNC)(CN $\left.{ }^{t} \mathrm{Bu}\right) \mathrm{Tl}$ ” that forms the crystal structure in 4). The geometric parameters of the optimized structures (Tables S2-S4 and Figures S8-S10 in the Supplementary Information) are in good agreement with the X-ray structural analysis data. Relevant data on the calculated low-energy electronic transitions in gas phase and the frontier molecular orbital (MOs) involved in these are listed in Tables S5 and S6 (Supplementary Information).

The calculated low-energy transitions are in close agreement, within the accuracy of the method, with the experimentally observed absorption maxima (Figure 9). In both complexes, the lowest lying absorption (S1) involves the HOMO $\rightarrow$ LUMO transition $[\lambda$ : $433.5 \mathrm{~nm}$ (98.5\%), 2; $452.9 \mathrm{~nm}$ (97.6\%), 4']. The HOMO is mostly located on the CNC (74\% 2 - 86\% 4') and the platinum centre (24\% 2 - 14\% 4') whereas the LUMO is constructed from orbitals located on the CNC (79\% 2 - 62\% 4'), the platinum centre (13\% 2 - 16\% 4'), the isocyanide ligand (8\% 2 - 8\% 4') and the thallium centre (14\%, 4'). Thus, the formation of the $\mathrm{Pt}(\mathrm{II})-\mathrm{Tl}(\mathrm{I})$ bond produces a significant change in the nature of the lower unoccupied orbitals (LUMO and L+1), which now have a significant contribution from the thallium orbitals, as previously reported elsewhere. ${ }^{54,56,64}$ The S1 calculated absorptions are assigned to an intraligand $\left[{ }^{1} \mathrm{IL}, \pi-\pi^{*}(\mathrm{CNC})\right]$ transition mixed with some metal-to-ligand charge transfer $\left[{ }^{1} \mathrm{MLCT},\left(5 \mathrm{~d}(\mathrm{Pt}) \rightarrow \pi^{*}(\mathrm{CNC})\right]\right.$ character for both 2 and 4' but moreover, in the case of 4', with an additional contribution of a ligand-to-metal charge transfer [ ${ }^{1} \mathrm{LMM}{ }^{\prime} \mathrm{CT}, \pi(\mathrm{CNC}) \rightarrow(\mathrm{d} / \mathrm{s}(\mathrm{Pt}, \mathrm{Tl})]$.

Nonetheless, as seen in Figure 9, the most important low energy absorptions (S3) calculated for $\mathbf{2}$ and 4' are 330.5 and $353.3 \mathrm{~nm}$, respectively. They mainly involve the following transitions: $\mathrm{H} \rightarrow \mathrm{L}+1$ (87.1\%, 2) and $\mathrm{H}-1 \rightarrow \mathrm{L}$ (84.8\%, 4'). The frontier orbitals involved in them are very similar to those of S1. The unoccupied orbital $L+1$ in 2 (see Figure S11, Supplementary Material) is mostly based on the CNC ligand (97\%). Therefore, in $\mathbf{2}$ the calculated absorption S3 arises from a metal perturbed intraligand $\left[{ }^{1} \mathrm{IL}, \pi-\pi^{*}(\mathrm{CNC})\right]$ transition. ${ }^{88}$ When comparing the DFT analysis of 2 with that of [Pt(Ethyl-2,6-diphenylisonicotinate) $\left.\left(\mathrm{CN}^{t} \mathrm{Bu}\right)\right],{ }^{88}$ a few differences can be observed. The 
LUMO is mostly located on the isonicotinic moiety of the CNC ligand with a considerable participation of the ethyl acetate, an electron-withdrawing group, which lowers the LUMO energy. As a consequence of this, both calculated and experimental absorptions are shifted to lower energies in relation to those of $\mathbf{2}$, as indicated in the UV-vis section.

The occupied orbital H-1 in 4' is also largely located on the CNC (92\%), more precisely on the phenyl ring opposite to the Pt-Tl bond. The electronic transition S3 is associated with the same metal perturbed intraligand $\left[{ }^{1} \mathrm{IL}, \pi-\pi^{*}\right.$ (CNC)] transition mixed with a ligand-to-metal [ ${ }^{1} \mathrm{LMM}^{\prime} \mathrm{CT}, \pi(\mathrm{CNC}) \rightarrow(\mathrm{d} / \mathrm{s}(\mathrm{Pt}, \mathrm{Tl})]$ charge transfer. All these calculated results are in close agreement with former assignments made in the absorption spectroscopy section.

Hence, the formation of the $\mathrm{Pt}-\mathrm{Tl}$ dative bond certainly leads to the stabilization of the HOMO (2.95 eV) reducing the weight of the Pt orbitals (14\%, 4'vs 24\%, 2) but it also produces an even greater stabilization in the LUMO (3.18 eV). Nevertheless, the overall effect in the transition energy is small (H-L gap: $3.83 \mathrm{eV}, 4$ ' vs $4.06 \mathrm{eV}, 2$ ) and not always accompanied by the expected hypsochromic shift, as observed in the UV-vis spectra and in related examples found in the literature. ${ }^{17,84}$

To further evaluate this Pt-Tl interaction and its importance in the nature of the emission, the structure of the first excited state $\mathrm{T}_{1}$ of 4' was optimized (see Figure S10 and Table S4 in the Supplementary Information). $\mathrm{T}_{1}$ shows a similar structure to that of the $\mathrm{S}_{0}$ state but with significant differences: the Pt-Tl distance increased from $3.062 \AA$ $\left(\mathrm{S}_{0}\right)$ to $3.146 \AA\left(\mathrm{T}_{1}\right)$, and the CNC ligand deviates slightly from planarity.

In addition, both NBO and Mayer bond order analyses were carried out in the $\mathrm{S}_{0}$ and $T_{1}$ states. In the Ground State $\left(\mathrm{S}_{0}\right)$ there is a substantial bonding interaction between the Pt-Tl atoms (bond order $=0.240$ ), as shown in the image of $\mathrm{H}-5$ (Figure S12, Supplementary Material). As mentioned above, this Pt-Tl interaction is significantly weakened in the first excited state $\left(T_{1}\right)$, showing a bond order of 0.1365 , which is in accordance with the longer Pt-Tl distance with respect to the ground state (see above). This also agrees with the slight Pt-Tl antibonding character of the LUMO. Therefore, the Pt-Tl bond is expected to have a certain contribution in the excited state and consequently in emissive properties. 
Emission Spectroscopy. All complexes are photoluminescent in the solid state and in glassy solutions of $\mathrm{CH}_{2} \mathrm{Cl}_{2}$ at $77 \mathrm{~K}$. The corresponding emission data are shown in Table 4.

Solid state emissions of $\mathbf{1 - 4}$ are rather weak at room temperature, but they turn out to be brightly emissive upon cooling to $77 \mathrm{~K}$. The mononuclear complexes $\mathbf{1}$ and 2 show very broad and slightly structured bands at room temperature with maxima at 666 and $600 \mathrm{~nm}$ respectively. These emissions became less structured with reduced bandwidths and red-shifted when cooled down to $77 \mathrm{~K}$ (see Figure S13, Supplementary Information). With regard to emission shape and energies along with their respective lifetimes, these were comparable to those of the neutral complexes $[\mathrm{Pt}(\mathrm{CNC}) \mathrm{L}]^{93,} 104$ and $\left[\mathrm{Pt}(2,6-\right.$ diphenylisonicotinate $\left.)\left(\mathrm{CN}^{t} \mathrm{Bu}\right)\right] .{ }^{88}$ Hence, the emissive behaviour of the mononuclear complexes $\mathbf{1}$ and $\mathbf{2}$ is correspondingly attributed to ${ }^{3} \pi \pi^{*}$ excimeric emissions.

The heteropolynuclear complexes $\mathbf{3}$ and $\mathbf{4}$ display unstructured bands with the corresponding maxima at $c a .600$ and $735 \mathrm{~nm}$ and with barely any changes in shape or energy upon cooling to $77 \mathrm{~K}$. However, the emissive behaviour (energy shiftings) of the Pt-Tl derivatives compared to their own precursors is totally different, as shown in Figure 10. The emission in $\mathbf{3}$ is substantially blue shifted, whereas, that in $\mathbf{4}$ is red shifted when compared to the corresponding starting materials $\mathbf{1}$ and $\mathbf{2}$. In line with earlier published results of $\mathrm{Pt} \rightarrow \mathrm{M}$ dative bonds, ${ }^{2,}{ }^{3,22}$ it seems that the structural arrangement in 3 , which holds the thallium centre tightly between the $\mathrm{Pt}_{3}$ core with a rather short donor-acceptor $\mathrm{Pt}-\mathrm{Tl}$ bond distance, would induce the remarkable hypsochromic shift in the emission band. Unlike compound 3, the emission band in $\mathbf{4}$ seems to come from a different emissive state. Considering the energy and shape of the band, its lifetime and the close Pt $\cdots \mathrm{Tl}, \pi \cdots \pi$ and $\mathrm{Tl} \cdots \pi$ contacts found in the extended lattice of the crystal structure, it seems reasonable to attribute the emission to a excimeric transition.

Glassy solutions of $\mathbf{1}$ in $\mathrm{CH}_{2} \mathrm{Cl}_{2}$ at $77 \mathrm{~K}$ display strongly structured emissions with vibronic spacings that match the skeletal vibrational frequencies of the CNC ligand at concentrations ranging from $10^{-5} \mathrm{M}$ up to $10^{-3} \mathrm{M}$ (Figure S14). On the other hand, the emission profile of glassy solutions of 2 in $\mathrm{CH}_{2} \mathrm{Cl}_{2}$ shows a low-energy (LE) unstructured band with maxima at $c a .630 \mathrm{~nm}$ regardless of the concentration $\left(10^{-5} \mathrm{M}-\right.$ $\left.10^{-3} \mathrm{M}\right)$. It is only in the diluted solutions $\left(10^{-5} \mathrm{M}\right)$ that an additional and extremely 
weak structured emission appears at higher energies (HE; 476, $514 \mathrm{~nm}$ ). The lifetime measurements determined for the high-energy (HE) fit one rather long component ( $\tau$ $21 \mu$ s (1); $39 \mu$ s (2)) whereas the low-energy (LE) bands give short lifetimes ( $\tau \sim 4 \mu \mathrm{s}$ (1); $2.7 \mu \mathrm{s}$ (2)). Therefore, considering all these data, the excitation spectra and the good concordance with previous "Pt(CNC)" studies, ${ }^{17,88,93,101,104,125}$ it can be considered that the HE band, which is the predominant one in $\mathbf{1}$, comes from a metal perturbed ${ }^{3}$ ILCT excited state involving the CNC ligand whilst the LE band, mainly observed in 2 , is most probably due to ${ }^{3} \pi \pi^{*}$ excimeric transitions.

In line with what has been reported in the DFT and UV-vis section, the emissions of the analogous derivatives with the substituted R-CNC ligand (2,6diphenylisonicotinate, $\mathrm{R}=\mathrm{COOEt})^{88}$ are substantially red-shifted in relation to those recorded in compounds $\mathbf{1}$ and $\mathbf{2}$ whether in solid state or rigid matrix.

In the heteropolynuclear compounds $\mathbf{3}$ and $\mathbf{4}$, the emissive behaviour of glassy solutions is different to that observed in the corresponding precursors (1 and $\mathbf{2}$ ) see Figures 11 and 12. The emission spectra of diluted solutions $\left(10^{-5} \mathrm{M}\right)$ of $\mathbf{3}$ are slightly dependent on the excitation wavelength, see Figure 11 . When exciting at $\lambda_{\text {ex }}<360 \mathrm{~nm}$, the emission comprises two distinct bands, one strong low energy band with maxima at $610 \mathrm{~nm}$ and one structured high-energy band (509, $546 \mathrm{~nm})$. Upon exciting at longer wavelengths ( $\lambda_{\mathrm{ex}}>380 \mathrm{~nm}$ ), the HE band becomes significantly less intense, being the one at $610 \mathrm{~nm}$ the predominant over the entire spectrum. The lifetime measurements, the excitation and emission profiles of this HE band resemble those found in $\mathbf{1}$. In concentrated solutions $\left(10^{-3} \mathrm{M}\right)$ of 3 , there is no evidence of this HE band. Both excitation and emission spectra show low energy bands that perfectly match those observed in the solid state and also the LE emission $(610 \mathrm{~nm})$ recorded in $10^{-5} \mathrm{M}$ solution. Lifetime measurements fit to a single exponential $\left(\lambda_{\mathrm{em}} 610 \mathrm{~nm}\right.$ : $3.1 \mu \mathrm{s}\left(10^{-3} \mathrm{M}\right)$ and $\left.5 \mu \mathrm{s}\left(10^{-5} \mathrm{M}\right)\right)$ and are typical of phosphorescent processes.

Similarly to compound 3, the emission of 4 in $\mathrm{CH}_{2} \mathrm{Cl}_{2}\left(10^{-5} \mathrm{M}\right)$ at $77 \mathrm{~K}$ consists of two bands (see Figure 12). In this case, regardless of the excitation wavelength, the spectrum shows a very intense low-energy emission centered at $c a .612 \mathrm{~nm}$ and the HE structured emission that is barely noticeable (HE; 476, $514 \mathrm{~nm}$ ). However, upon increasing the concentration to $10^{-3} \mathrm{M}$, the excitation and emission profiles become wavelength-dependent, which once again suggests the presence of different emissive 
states. The emission spectra monitored at $\lambda_{\mathrm{ex}}<440 \mathrm{~nm}$ show an unstructured band at $615 \mathrm{~nm}$, with a modest shoulder at $690 \mathrm{~nm}$. Upon excitation with wavelengths between $450-500 \mathrm{~nm}$, this incipient shoulder led to the formation of a second unstructured band shifted to lower energies $(720 \mathrm{~nm})$ that co-exists with the former one (see Figure S15, Supplementary Information). Finally, the emission spectra recorded at $\lambda_{\text {ex }}>500 \mathrm{~nm}$ only display this second band, which agrees well with the solid state emission. Taking all this into account and also the differences in the excitation spectra (See Figure 12), it seems plausible to propose two different emissive states associated with excimers and/or aggregates based on the different degrees of Pt $\cdots \mathrm{Tl}$ interactions within the Pt-Tl moeities. Furthermore, the structured HE bands that are extremely weak and only noticeable in diluted solutions of $\mathbf{3}$ and $\mathbf{4}$ seem to be comparable to those of $\mathbf{1}$ and $\mathbf{2}$, since their lifetime measurements, excitation and emission profiles are very much alike. Thus, the same ${ }^{3}$ ILCT (CNC) excited state is proposed for these emissions.

Following a similar procedure to the ${ }^{195} \mathrm{Pt}$ NMR experiments, an excess of $\mathrm{TlPF}_{6}$ was added to solutions of $\mathbf{3}$ and $\mathbf{4}$. The corresponding UV-vis and emission spectra were recorded, and no changes were observed; they exhibited the same bands to those of $\mathbf{3}$ and 4 (see Figure S16 and S17, Supplementary Information). Therefore, no other Pt-Tl species were detected either by NMR, UV-vis or photoluminescence spectroscopic techniques.

According to all these results, it could be concluded that the emissions of $\mathbf{3}$ and $\mathbf{4}$ in concentrated $\left(10^{-3} \mathrm{M}\right)$ solutions and, in the case of 3 , in diluted $\left(10^{-5} \mathrm{M}\right)$ solutions too, are analogous to those obtained in the solid state, where the Pt-Tl bond existence was confirmed by several characterization and spectroscopic techniques (X-ray diffraction, solid state ${ }^{195}$ Pt NMR, diffused reflectance).

\section{Conclusions}

The square planar Pt(II) complexes $\mathbf{1}$ and $\mathbf{2}$ have proved to be adequate precursors in the preparation of complexes containing $\mathrm{Pt} \rightarrow \mathrm{Tl}$ dative bonds unsupported by any bridging ligand (3 and 4). The solid state geometries of these clusters are striking, since the platinum moieties adopt a triangular disposition that gives rise to a cavity in which the thallium centres are located. It seems that the size of this cavity is determined by the steric requirements of the ligand bonded in the "fourth" coordination position of the 
platinum. The tht ligand is smaller and more flexible than the $\mathrm{CN}^{t} \mathrm{Bu}$ and thus it is able to bend away. Hence the triangular cavity in $\mathbf{3}$ is only able to host a $\mathrm{Tl}$ centre, resulting in a trigonal environment for it and the formation of three $\mathrm{Pt}-\mathrm{Tl}$ bonds involving a single Tl atom. All three Pt-Tl distances are 2.9086(5) $\AA$, the shortest reported so far for a $\mathrm{Pt}(\mathrm{II})-\mathrm{Tl}(\mathrm{I})$ bond unassisted by any bridging ligand or by pairing $(\mathrm{PtTl})_{2}$ metallocycle systems. Furthermore, the size of the cavity in $\mathbf{4}$ allows three $\mathrm{Tl}$ atoms to be accommodated, resulting again in three Pt-Tl bonds that are slightly longer than in $\mathbf{3}$ (3.0143(3), 3.0488(3) and 3.0460(3) A), but still remarkably short. The presence of the $\eta^{6}$-Tl-arene interactions in $\mathbf{4}$ is also noteworthy since they are responsible for the integrity of the $(\mathrm{PtTl})_{3}$ cluster.

The NMR studies support the idea that the Pt-Tl bonds persist in solution. The best evidence is obtained for $\mathbf{3}$ in terms of downfield shift of the signal and presence of Pt-Tl coupling in its ${ }^{195} \mathrm{Pt}\left\{{ }^{1} \mathrm{H}\right\} \mathrm{NMR}$ spectra in $\mathrm{CD}_{2} \mathrm{Cl}_{2}$ solution. In the case of $\mathbf{4}$, only a less pronounced downfield shift was observed. Nevertheless, it seems clear that these clusters dissociates in solution to give equilibrium mixtures of different $\mathrm{Pt} / \mathrm{Tl}$ species on the ${ }^{195} \mathrm{Pt}$ NMR time scale. These equilibria can be tuned up by adding an excess of $\mathrm{TlPF}_{6}$ or by lowering the temperature, but in the case of $\mathbf{4}$ this is not enough to produce a greater downfield shift of the ${ }^{195} \mathrm{Pt}$ signal or a clear Pt-Tl coupling. This fact could be due to the greater robustness of the Pt-Tl bonds for $\mathbf{3}$ than for $\mathbf{4}$, and that the trigonal $\mathrm{Pt}_{3} \mathrm{Tl}$ disposition found in $\mathbf{3}$ is remarkably stable.

The DFT studies on compounds 2 and 4' correlates well with the UV-vis experiments. The formation of $\mathrm{Pt}-\mathrm{Tl}$ dative bonds does not produce the expected blueshift in the absorption bands since not only the HOMO but also the LUMO undergo an energy stabilization, producing an almost unnoticeable overall effect. In solid state, the emission of $\mathbf{3}$ is considerably shifted to higher energies whereas that of $\mathbf{4}$ is shifted to lower energies when compared to the corresponding starting materials. The emissive behaviour of $\mathbf{3}$ and $\mathbf{4}$ in concentrated solutions is comparable to that observed in the solid state, where the existence of the $\mathrm{Pt}-\mathrm{Tl}$ bond was established by different techniques.

\section{Experimental}

\section{General considerations.}


A modification of the method reported in the literature ${ }^{100}$ was used to prepare the starting material $[\mathrm{Pt}(\mathrm{CNC})(\mathrm{dmso})]$ (CNC $=$ 2,6-diphenylpyridinate) (see below). Elemental analyses were carried out with a Perkin-Elmer 2400 CHNS analyzer. IR spectra were recorded on a Perkin-Elmer Spectrum 100 FT-IR spectrometer (ATR in the range 250-4000 $\mathrm{cm}^{-1}$ ). Mass spectrometry was performed with the Microflex matrixassisted laser desorption ionization-time-of-flight (MALDI-TOF) Bruker or an Autoflex III MALDI-TOF Bruker instruments. ${ }^{1} \mathrm{H}$ and ${ }^{195} \mathrm{Pt}\left\{{ }^{1} \mathrm{H}\right\}$ NMR spectra were recorded on a Bruker AV-400 spectrometer using the standard references: $\mathrm{SiMe}_{4}$ for ${ }^{1} \mathrm{H}$ and $\mathrm{Na}_{2} \mathrm{PtCl}_{6}$ in $\mathrm{D}_{2} \mathrm{O}$ for the ${ }^{195} \mathrm{Pt}$. Solid state ${ }^{195} \mathrm{Pt}$ NMR experiments were acquired using a Bruker AV-400 WB and they were referenced to $\mathrm{Na}_{2} \mathrm{PtCl}_{6}$. The crystalline samples of 1-4 were packed in $4 \mathrm{~mm}$ o.d. zirconium oxide rotors and were placed within a $4 \mathrm{~mm}$ MAS BB- H1 probe at $25{ }^{\circ} \mathrm{C}$. Solid state NMR spectra of $\mathbf{1 - 4}$ were recorded at different spinning speeds: 5, 8 and $12 \mathrm{kHz}$ using the hpdec pulse program. Molar conductances were carried out on a Philiphs PW9509 conductimeter in acetone solution $\left(5 \times 10^{-4} \mathrm{M}\right)$. Diffuse reflectance UV-vis (DRUV) spectra were recorded on a Jasco electron corporation evolution V670 spectrophotometer equipped with a Praying Mantis integrating sphere. The solid samples were homogeneously diluted with silica. The mixtures were placed in a homemade cell equipped with quartz window. Steady-state photoluminescence spectra were recorded on a Jobin-Yvon Horiba Fluorolog FL-3-11 Tau 3 spectrofluorimeter using band pathways of $3 \mathrm{~nm}$ for both excitation and emission. Phosphorescence lifetimes were recorded with a Fluoromax phosphorimeter accessory containing a UV xenon flash tube with a flash rate between 0.05 and $25 \mathrm{~Hz}$. Phase shift and modulation were recorded over the frequency range of 0.1-100 MHz. Nanosecond lifetimes were recorded with a Datastation HUB-B with a nanoLED controller and software DAS6. The nanoLED employed for lifetime measurement were of $483 \mathrm{~nm}$ with pulse lengths of $<1.4$ ns. The lifetime data were fitted using the Jobin-Yvon software package and the Origin Pro 8 program.

Preparation of $[\mathbf{P t}(\mathbf{C N C})(\mathbf{d m s o})]$. Potassium tetrachloroplatinate (0.638 g, 1.540 mmol) previously pulverized was added to a solution of 2,6-diphenylpyridine (0.463 g, $2.000 \mathrm{mmol})$ in glacial acetic acid $(125 \mathrm{ml})$. The reaction mixture was stirred at $126 \mathrm{C}$ under an Ar atmosphere until the red platinum salt was no longer visible (2 days). The reaction mixture was filtered, yielding the product $[\mathrm{Pt}(\mathrm{CNC}-\mathrm{H})(\mu-\mathrm{Cl})]_{2}$ as an insoluble yellow powder which was washed with water, $\mathrm{MeOH}$ and diethyl ether (0.644 g, 91\%). 
This $[\mathrm{Pt}(\mathrm{CNC}-\mathrm{H})(\mu-\mathrm{Cl})]_{2}(0.250 \mathrm{~g}, 0.271 \mathrm{mmol})$ was dissolved in hot dmso $(6 \mathrm{~mL})$ and the reaction was stirred at $100 \mathrm{C}$ for $5 \mathrm{~min}$. The solution obtained was filtered through celite and washed with hot dmso (110 C). The solution was then allowed to reach room temperature and was added $40 \mathrm{~mL}$ of $\mathrm{H}_{2} \mathrm{O}$ and $\mathrm{Na}_{2} \mathrm{CO}_{3}(0.040 \mathrm{~g}, 0.377 \mathrm{mmol})$. The resulting yellow suspension was stirred for $1 \mathrm{~h}$ and then filtered off, washed with $\mathrm{H}_{2} \mathrm{O}$ and re-dissolved in $\mathrm{CH}_{2} \mathrm{Cl}_{2}$. To this solution, $\mathrm{MgSO}_{4}$ and activated carbon were added and it was stirred for $5 \mathrm{~min}$, after which it was filtered through celite and evaporated to dryness. Diethyl eter $(10 \mathrm{~mL})$ was added on the solid, and the resulting suspension was filtered off and air dried (0.204, 75\%).

Preparation of $[\operatorname{Pt}(\mathbf{C N C})($ tht $)]$ (1). To a solution of [Pt(CNC)(dmso)] (0.103g, 0.205 $\mathrm{mmol})$ in $\mathrm{MeOH}(30 \mathrm{~mL})$ at room temperature, $36.2 \mu \mathrm{l}$ of tht $(0.410 \mathrm{mmol}, 100 \%$ excess) was added. After 4 days of stirring the solution was concentrated until ca. $2 \mathrm{~mL}$. The yellow precipitate which appeared was filtered off, washed with $n$-hexane (10 mL) and air dried (0.086 g, 82\%). Anal. Found: C, 49.01; H, 3.71; N, 2.85; S, 5.77. Calcd for $\mathrm{C}_{21} \mathrm{H}_{19} \mathrm{NPtS}$ : C, 49.21; H, 3.74; N, 2.73; S, $6.26 \%$. IR ( $\left.v_{\max } / \mathrm{cm}^{-1}\right)$ : 1598w (NC), 1575w (NC), 1561w (NC), 1542w (NC), 1267w (SC), 1251w (SC). $\Lambda_{\mathrm{M}}$ (acetone) $=2.64 \Omega^{-1}$ $\mathrm{cm}^{2} \mathrm{~mol}^{-1} .{ }^{1} \mathrm{H}$ NMR (400.132 MHz, $\mathrm{CD}_{2} \mathrm{Cl}_{2}$, 293K. See Scheme 2 for the $\mathrm{H}$ numbering scheme): $\delta=7.61\left(1 \mathrm{H}, \mathrm{t},{ }^{3} J_{\mathrm{H} 7-\mathrm{H} 6}=8.0 \mathrm{~Hz}, \mathrm{H} 7\right), 7.52\left(2 \mathrm{H}, \mathrm{dd},{ }^{3} J_{\mathrm{Pt}-\mathrm{H}}=21.6 \mathrm{~Hz},{ }^{3} J_{\mathrm{H} 2-\mathrm{H} 3}=\right.$ $\left.7.5 \mathrm{~Hz},{ }^{4} J_{\mathrm{H} 2-\mathrm{H} 4}=1.3 \mathrm{~Hz}, \mathrm{H} 2\right), 7.48\left(2 \mathrm{H}, \mathrm{dd},{ }^{3} J_{\mathrm{H} 5-\mathrm{H} 4}=7.5 \mathrm{~Hz},{ }^{4} J_{\mathrm{H} 5-\mathrm{H} 3}=1.1 \mathrm{~Hz}, \mathrm{H} 5\right), 7.31$ $\left(2 \mathrm{H}, \mathrm{d},{ }^{3} J_{\mathrm{H} 6-\mathrm{H} 7}=8.0 \mathrm{~Hz},{ }^{4} J_{\mathrm{Pt}-\mathrm{H} 6}=10.4 \mathrm{~Hz}, \mathrm{H} 6\right), 7.22\left(2 \mathrm{H}, \mathrm{ddd},{ }^{3} J_{\mathrm{H} 3-\mathrm{H} 4}=7.4 \mathrm{~Hz},{ }^{3} J_{\mathrm{H} 3-\mathrm{H} 2}=\right.$ $\left.7.5 \mathrm{~Hz},{ }^{4} J_{\mathrm{H} 3-\mathrm{H} 5}=1.1 \mathrm{~Hz}, \mathrm{H} 3\right), 7.07\left(2 \mathrm{H}, \mathrm{ddd},{ }^{3} J_{\mathrm{H} 4-\mathrm{H} 3}=7.4 \mathrm{~Hz},{ }^{3} J_{\mathrm{H} 4-\mathrm{H} 5}=7.5 \mathrm{~Hz},{ }^{4} J_{\mathrm{H} 4-\mathrm{H} 2}=\right.$ $1.3 \mathrm{~Hz}, \mathrm{H} 4), 3.56\left(4 \mathrm{H}, \mathrm{t},{ }^{3} J_{\mathrm{Pt}-\mathrm{H} \alpha}=52.9 \mathrm{~Hz},{ }^{3} J_{\mathrm{H} \alpha-\mathrm{H} \beta}=6.5 \mathrm{~Hz}, \mathrm{H}-\alpha-\mathrm{tht}\right), 2.16\left(4 \mathrm{H}, \mathrm{t},{ }^{3} J_{\mathrm{H} \beta-\mathrm{H} \alpha}\right.$ $=6.5 \mathrm{~Hz}, \mathrm{H}-\beta$-tht $)$ ppm. ${ }^{13} \mathrm{C}\left\{{ }^{1} \mathrm{H}\right\} \mathrm{NMR}\left(100.624 \mathrm{MHz}, \mathrm{CD}_{2} \mathrm{Cl}_{2}, 293 \mathrm{~K}\right): \delta=169.0\left(\mathrm{~s}, J_{\mathrm{C}}\right.$ $\mathrm{Pt}=714.4, \mathrm{C} 1), 167.3$ (s, $\left.{ }^{2} J_{\mathrm{C}-\mathrm{Pt}}=73.7, \mathrm{C} 8\right), 150.5$ (s, $\left.{ }^{2} J_{\mathrm{C}-\mathrm{Pt}}=47.1, \mathrm{C} 9\right), 140.4$ (s, C7), $136.7\left(\mathrm{~s},{ }^{2} J_{\mathrm{C}-\mathrm{Pt}}=44.7, \mathrm{C} 2\right), 130.9\left(\mathrm{~s},{ }^{3} J_{\mathrm{C}-\mathrm{Pt}}=29.0, \mathrm{C} 3\right), 124.6\left(\mathrm{~s},{ }^{3} J_{\mathrm{C}-\mathrm{Pt}}=26.4, \mathrm{C} 5\right), 124.3$ (s, C4), 115.3 (s, $\left.{ }^{4} J_{\mathrm{C}-\mathrm{Pt}}=37.4, \mathrm{C} 6\right), 40.6$ (s, C- $\alpha$-tht), 30.4 (s, C- $\beta$-tht) ppm. ${ }^{195} \mathrm{Pt}\left\{{ }^{1} \mathrm{H}\right\}$ NMR (85.679 MHz, $\left.\mathrm{CD}_{2} \mathrm{Cl}_{2}\right): \delta=-3914$ (t, $\left.J_{\mathrm{Pt}-\mathrm{N}}=264.4 \mathrm{~Hz}\right)(293 \mathrm{~K}),-3901$ (s) (193K) ppm. Solid state ${ }^{195} \mathrm{Pt}\left\{{ }^{1} \mathrm{H}\right\}$ NMR (85.6 MHz): $\delta=-3816$ ppm. Mass spectra MALDI+ DIT: $m / z=513\left[\mathrm{Pt}\left(\mathrm{C}_{17} \mathrm{H}_{11} \mathrm{~N}\right)\left(\mathrm{C}_{4} \mathrm{H}_{8} \mathrm{~S}\right) \mathrm{H}\right]^{+}$.

Preparation of $\left[\mathrm{Pt}(\mathbf{C N C})\left(\mathrm{CN}^{t} \mathrm{Bu}\right)\right]$ (2). To a solution of $[\mathrm{Pt}(\mathrm{CNC})(\mathrm{dmso})](0.20 \mathrm{~g}$, $0.398 \mathrm{mmol})$ in $\mathrm{MeOH}(20 \mathrm{~mL})$ at room temperature, $54.0 \mu \mathrm{l}$ of tht $(0.477 \mathrm{mmol}, 20 \%$ excess) was added. After 4 days of stirring the solution was concentrated until ca. $2 \mathrm{~mL}$. The yellow precipitate which appeared was filtered off, washed with $n$-hexane $(10 \mathrm{~mL})$ 
and air dried (0.169 g, 83\%). Anal. Found: C, 52.02; H, 3.90; N, 5.62. Calcd for $\mathrm{C}_{22} \mathrm{H}_{20} \mathrm{~N}_{2} \mathrm{Pt}$ : C, 52.07; H, 3.97; N, $5.52 \%$. IR ( $\left.v_{\max } / \mathrm{cm}^{-1}\right)$ : 2164s (NC), 1597m (NC), 1576w (NC), 1560w (NC), 1543w (NC), 1205w. $\Lambda_{\mathrm{M}}$ (acetone) $=1.08 \Omega^{-1} \mathrm{~cm}^{2} \mathrm{~mol}^{-1}$. ${ }^{1} \mathrm{H}$ NMR (400.132 MHz, $\left.\mathrm{CD}_{2} \mathrm{Cl}_{2}, 293 \mathrm{~K}\right): \delta=7.62\left(2 \mathrm{H}, \mathrm{dd},{ }^{3} J_{\mathrm{Pt}-\mathrm{H}}=32.1 \mathrm{~Hz},{ }^{3} J_{\mathrm{H} 2-\mathrm{H} 3}=7.0\right.$ $\left.\mathrm{Hz},{ }^{4} J_{\mathrm{H} 2-\mathrm{H} 4}=0.8 \mathrm{~Hz}, \mathrm{H} 2\right), 7.61\left(1 \mathrm{H}, \mathrm{t},{ }^{3} J_{\mathrm{H} 7-\mathrm{H} 6}=8.0 \mathrm{~Hz}, \mathrm{H} 7\right), 7.44\left(2 \mathrm{H}, \mathrm{d},{ }^{3} J_{\mathrm{H} 5-\mathrm{H} 4}=7.6\right.$ $\mathrm{Hz}, \mathrm{H} 5), 7.29\left(2 \mathrm{H}, \mathrm{d},{ }^{3} J_{\mathrm{H} 6-\mathrm{H} 7}=8.0 \mathrm{~Hz},{ }^{4} J_{\mathrm{Pt}-\mathrm{H} 6}=7.9 \mathrm{~Hz}, \mathrm{H} 6\right), 7.19\left(2 \mathrm{H}, \mathrm{ddd},{ }^{3} J_{\mathrm{H} 3-\mathrm{H} 4}=7.3\right.$ $\left.\mathrm{Hz},{ }^{3} J_{\mathrm{H} 3-\mathrm{H} 2}=7.0 \mathrm{~Hz},{ }^{4} J_{\mathrm{H} 3-\mathrm{H} 5}=1.2 \mathrm{~Hz}, \mathrm{H} 3\right), 7.07\left(2 \mathrm{H}, \mathrm{ddd},{ }^{3} J_{\mathrm{H} 4-\mathrm{H} 5}=7.6 \mathrm{~Hz},{ }^{3} J_{\mathrm{H} 4-\mathrm{H} 3}=7.3\right.$ $\left.\mathrm{Hz},{ }^{4} J_{\mathrm{H} 4-\mathrm{H} 2}=1.3 \mathrm{~Hz}, \mathrm{H} 4\right), 1.69\left(9 \mathrm{H}, \mathrm{s}, \mathrm{H}-{ }^{\mathrm{t}} \mathrm{BuCN}\right) \mathrm{ppm} .{ }^{13} \mathrm{C}\left\{{ }^{1} \mathrm{H}\right\} \mathrm{NMR}(100.624 \mathrm{MHz}$, $\mathrm{CD}_{2} \mathrm{Cl}_{2}, 293 \mathrm{~K}$ ): $\delta=168.8$ (s, $J_{\mathrm{C}-\mathrm{Pt}}=665.6, \mathrm{C} 1$ ), 168.5 (s, C8), 150.4 (s, C9), 141.3 (s, C7), $139.8\left(\mathrm{~s},{ }^{2} J_{\mathrm{C}-\mathrm{Pt}}=69.7, \mathrm{C} 2\right), 131.7\left(\mathrm{~s},{ }^{3} J_{\mathrm{C}-\mathrm{Pt}}=36.7, \mathrm{C} 3\right), 124.6\left(\mathrm{~s},{ }^{3}\right.$ or ${ }^{4} J_{\mathrm{C}-\mathrm{Pt}}=26.4,{ }^{3 \text { or }}$ ${ }^{4} J_{\mathrm{C}-\mathrm{Pt}}=24.0$, C5 y C4), $115.7\left(\mathrm{~s},{ }^{4} J_{\mathrm{C}-\mathrm{Pt}}=30.5, \mathrm{C} 6\right), 58.4(\mathrm{~s}, \mathrm{C} \equiv \mathrm{N}), 31.1\left(\mathrm{~s}, \mathrm{C}-\mathrm{Me}_{3}\right)$ ppm. ${ }^{195} \mathrm{Pt}\left\{{ }^{1} \mathrm{H}\right\}$ NMR (85.679 MHz, $\mathrm{CD}_{2} \mathrm{Cl}_{2}$ ): $\delta=-4051$ (s) (293K), -4076 (s) (193K) ppm. Solid state ${ }^{195} \mathrm{Pt}\left\{{ }^{1} \mathrm{H}\right\}$ NMR (85.6 MHz): $\delta=-4020$ ppm. Mass spectra MALDI+ DIT: $m / z=508\left[\mathrm{Pt}\left(\mathrm{C}_{17} \mathrm{H}_{11} \mathrm{~N}\right)\left(\mathrm{C}_{5} \mathrm{H}_{9} \mathrm{~N}\right) \mathrm{H}\right]^{+}, 452\left[\mathrm{Pt}\left(\mathrm{C}_{17} \mathrm{H}_{11} \mathrm{~N}\right)(\mathrm{NC}) \mathrm{H}\right]^{+}$.

Preparation of $\left[\{\mathbf{P t}(\mathbf{C N C})(\mathbf{t h t})\}_{3} \mathbf{T l}\right]\left(\mathbf{P F}_{6}\right)$ (3). To a yellow solution of $\mathbf{1}(0.100 \mathrm{~g}, 0.193$ $\mathrm{mmol})$ in $\mathrm{CH}_{2} \mathrm{Cl}_{2}(20 \mathrm{~mL})$ at room temperature, $\mathrm{TlPF}_{6}(0.023 \mathrm{~g}, 0.064 \mathrm{mmol})$ was added. The solution turns orange and after $90 \mathrm{~min}$ of stirring the solution was evaporated to dryness. Diethyl eter $(10 \mathrm{~mL})$ was added on the orange solid, and the resulting suspension was filtered off, washed with $n$-hexane $(10 \mathrm{~mL})$ and air dried (0.110 g, 90\%). Anal. Found: C, 39.69; H, 3.04; N, 2.39; S, 4.91. Calcd for $\mathrm{C}_{63} \mathrm{H}_{57} \mathrm{~F}_{6} \mathrm{~N}_{3} \mathrm{PPt}_{3} \mathrm{~S}_{3} \mathrm{Tl}: \mathrm{C}, 40.10 ; \mathrm{H}, 3.04 ; \mathrm{N}, 2.23 ; \mathrm{S}, 5.10 \%$. IR ( $\left.\mathrm{v}_{\max } / \mathrm{cm}^{-1}\right): 1596 \mathrm{w}(\mathrm{NC})$, 1580w (NC), 1559w v(NC), 1542w (NC), 1272w (SC), 1252w (SC), 833s $\left(\mathrm{PF}_{6}^{+}\right), 555 \mathrm{~m}$ $\left(\mathrm{PF}_{6}{ }^{+}\right) \cdot \Lambda_{\mathrm{M}}$ (acetone) $=256.96 \Omega^{-1} \mathrm{~cm}^{2} \mathrm{~mol}^{-1} \cdot{ }^{1} \mathrm{H} \mathrm{NMR}\left(400.132 \mathrm{MHz}, \mathrm{CD}_{2} \mathrm{Cl}_{2}, 293 \mathrm{~K}\right): \delta$ $=7.72\left(1 \mathrm{H}, \mathrm{t},{ }^{3} J_{\mathrm{H} 7-\mathrm{H} 6}=8.0 \mathrm{~Hz}, \mathrm{H} 7\right), 7.51\left(2 \mathrm{H}, \mathrm{dd},{ }^{3} J_{\mathrm{H} 5-\mathrm{H} 4}=7.6 \mathrm{~Hz},{ }^{4} J_{\mathrm{H} 5-\mathrm{H} 3}=1.1 \mathrm{~Hz}\right.$, H5), $7.38\left(2 \mathrm{H}, \mathrm{d},{ }^{3} J_{\mathrm{H} 6-\mathrm{H} 7}=8.0 \mathrm{~Hz},{ }^{4} J_{\mathrm{Pt}-\mathrm{H} 6}=9.7 \mathrm{~Hz}, \mathrm{H} 6\right), 7.15\left(2 \mathrm{H}, \mathrm{ddd},{ }^{3} J_{\mathrm{H} 4-\mathrm{H} 3}=7.4 \mathrm{~Hz}\right.$, $\left.{ }^{3} J_{\mathrm{H} 4-\mathrm{H} 5}=7.6 \mathrm{~Hz},{ }^{4} J_{\mathrm{H} 4-\mathrm{H} 2}=1.1 \mathrm{~Hz}, \mathrm{H} 4\right), 7.05\left(2 \mathrm{H}, \mathrm{ddd},{ }^{3} J_{\mathrm{H} 3-\mathrm{H} 4}=7.4 \mathrm{~Hz},{ }^{3} J_{\mathrm{H} 3-\mathrm{H} 2}=7.3 \mathrm{~Hz}\right.$, $\left.{ }^{4} J_{\mathrm{H} 3-\mathrm{H} 5}=1.1 \mathrm{~Hz}, \mathrm{H} 3\right), 6.86\left(2 \mathrm{H}, \mathrm{dd},{ }^{3} J_{\mathrm{Pt}-\mathrm{H}}=19.7 \mathrm{~Hz},{ }^{3} J_{\mathrm{H} 2-\mathrm{H} 3}=7.3 \mathrm{~Hz},{ }^{4} J_{\mathrm{H} 2-\mathrm{H} 4}=1.1, \mathrm{H} 2\right)$, $3.36\left(4 \mathrm{H}, \mathrm{t},{ }^{3} J_{\mathrm{Pt}-\mathrm{H}}=54.5 \mathrm{~Hz},{ }^{3} J_{\mathrm{H} \alpha-\mathrm{H} \beta}=6.2, \mathrm{H}-\alpha-\mathrm{tht}\right), 1.98$ (4H, b, H- $\beta-$ tht $) \mathrm{ppm} .{ }^{13} \mathrm{C}\left\{{ }^{1} \mathrm{H}\right\}$ NMR (100.624 MHz, $\left.\mathrm{CD}_{2} \mathrm{Cl}_{2}, 293 \mathrm{~K}\right): \delta=167.2$ (s, C8), 165.0 (s, C1), 150.1 (s, ${ }^{2} J_{\mathrm{C}-\mathrm{Pt}}=$ 46.0, C9), 140,9. (s, C7), 138.4 (s, ${ }^{2} J_{\mathrm{C}-\mathrm{Pt}}=42.2$, C2), 131.7 (s, $\left.{ }^{3} J_{\mathrm{C}-\mathrm{Pt}}=28.7, \mathrm{C} 3\right), 125.2$ $\left(\mathrm{s},{ }^{3}\right.$ or ${ }^{4} J_{\mathrm{C}-\mathrm{Pt}}=27.9,{ }^{3}$ or ${ }^{4} J_{\mathrm{C}-\mathrm{Pt}}=24.6$, C5 y C4), 116.0 (s, $\left.{ }^{4} J_{\mathrm{C}-\mathrm{Pt}}=37.6, \mathrm{C} 6\right), 43.1$ (s, C- $\alpha-$ tht), 30.5 (s, C- $\beta$-tht) ppm. ${ }^{19} \mathrm{~F}$ NMR (376.489 MHz, $\mathrm{CD}_{2} \mathrm{Cl}_{2}$ ): $\delta=-73.0$ (d, $J_{\mathrm{F}-\mathrm{P}=711.6}$

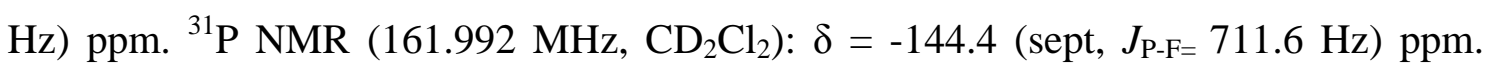
Solid state ${ }^{195} \mathrm{Pt}\left\{{ }^{1} \mathrm{H}\right\}$ NMR (85.6 MHz): $\delta=-3088\left(\mathrm{~d}, J_{\mathrm{Pt}-\mathrm{Tl}}=9.0 \mathrm{kHz}\right) \mathrm{ppm}$. Mass spectra 
MALDI+ DIT: $m / z=1477\left[\mathrm{TlPt}_{3}\left(\mathrm{C}_{17} \mathrm{H}_{11} \mathrm{~N}\right)_{3}\right]^{+}, 1053 \quad\left[\mathrm{TlPt}_{2}\left(\mathrm{C}_{17} \mathrm{H}_{11} \mathrm{~N}\right)_{2}\right]^{+}, \quad 849$ $\left[\mathrm{Pt}_{2}\left(\mathrm{C}_{17} \mathrm{H}_{11} \mathrm{~N}\right)_{2}\right]^{+}, 717\left[\mathrm{TlPt}\left(\mathrm{C}_{17} \mathrm{H}_{11} \mathrm{~N}\right)\left(\mathrm{C}_{4} \mathrm{H}_{8} \mathrm{~S}\right)\right]^{+}, 513\left[\mathrm{Pt}\left(\mathrm{C}_{17} \mathrm{H}_{11} \mathrm{~N}\right)\left(\mathrm{C}_{4} \mathrm{H}_{8} \mathrm{~S}\right) \mathrm{H}\right]^{+}$.

Preparation of $\left[\left\{\mathrm{PtTl}\left(\mathrm{C}_{17} \mathrm{H}_{11} \mathrm{~N}\right)\left(\mathrm{CN}^{t} \mathrm{Bu}\right)\right\}_{3}\right]\left(\mathbf{P F}_{6}\right)_{3}$ (4). To a yellow solution of $\mathbf{2}$ (0.100g, 0.199mmol) in $\mathrm{CH}_{2} \mathrm{Cl}_{2}(20 \mathrm{~mL})$ at room temperature, TlPF 6 (0.070 g, $0.199 \mathrm{mmol}$ ) was added. After $60 \mathrm{~min}$ of stirring the solution was concentrated until $c a$. $2 \mathrm{~mL}$. The orange precipitate which appeared was filtered off, washed with $n$-hexane (10 mL) and air dried (0.129 g, 76\%). Anal. Found: C, 30.45; H, 2.07; N, 3.46. Calcd for $\mathrm{C}_{22} \mathrm{H}_{20} \mathrm{~F}_{6} \mathrm{~N}_{2}$ PPtTl: C, 30.84; H, 2.07; N, 3.46\%. IR ( $\left.v_{\max } / \mathrm{cm}^{-1}\right)$ : 2168m (NC), 1598w (NC), 577w (NC), 1560w (NC), 1543w (NC), 1197w, 831s $\left(\mathrm{PF}_{6}^{+}\right), 554 \mathrm{~s}\left(\mathrm{PF}_{6}^{+}\right) \cdot \Lambda_{\mathrm{M}}$ (acetone) $=231.65 \Omega^{-1} \mathrm{~cm}^{2} \mathrm{~mol}^{-1} .{ }^{1} \mathrm{H}$ NMR (400.132 $\left.\mathrm{MHz}, \mathrm{CD}_{2} \mathrm{Cl}_{2}, 293 \mathrm{~K}\right): \delta=7.63(1 \mathrm{H}$, $\left.\mathrm{t},{ }^{3} J_{\mathrm{H} 7-\mathrm{H} 6}=8.0 \mathrm{~Hz}, \mathrm{H} 7\right), 7.60\left(2 \mathrm{H}, \mathrm{dd},{ }^{3} J_{\mathrm{Pt}-\mathrm{H}}=30.9 \mathrm{~Hz},{ }^{3} J_{\mathrm{H} 2-\mathrm{H} 3}=7.2 \mathrm{~Hz},{ }^{4} J_{\mathrm{H} 2-\mathrm{H} 4}=1.3 \mathrm{~Hz}\right.$, $\mathrm{H} 2), 7.44\left(2 \mathrm{H}, \mathrm{dd},{ }^{3} J_{\mathrm{H} 5-\mathrm{H} 4}=7.6 \mathrm{~Hz},{ }^{4} J_{\mathrm{H} 5-\mathrm{H} 3}=1.2 \mathrm{~Hz}, \mathrm{H} 5\right), 7.29\left(2 \mathrm{H}, \mathrm{d},{ }^{3} J_{\mathrm{H} 6-\mathrm{H} 7}=8.0 \mathrm{~Hz}\right.$, $\left.{ }^{4} J_{\mathrm{Pt}-\mathrm{H} 6}=7.8 \mathrm{~Hz}, \mathrm{H} 6\right), 7.20\left(2 \mathrm{H}\right.$, ddd, ${ }^{3} J_{\mathrm{H} 3-\mathrm{H} 4}=7.5 \mathrm{~Hz},{ }^{3} J_{\mathrm{H} 3-\mathrm{H} 2}=7.2 \mathrm{~Hz},{ }^{4} J_{\mathrm{H} 3-\mathrm{H} 5}=1.2 \mathrm{~Hz}$, H3), $7.09\left(2 \mathrm{H}, \mathrm{ddd},{ }^{3} J_{\mathrm{H} 4-\mathrm{H} 5}=7.6 \mathrm{~Hz},{ }^{3} J_{\mathrm{H} 4-\mathrm{H} 3}=7.5 \mathrm{~Hz},{ }^{4} J_{\mathrm{H} 4-\mathrm{H} 2}=1.3 \mathrm{~Hz}, \mathrm{H} 3\right), 1.67(9 \mathrm{H}$, s, H- $\left.{ }^{\mathrm{t}} \mathrm{BuCN}\right) \mathrm{ppm} .{ }^{13} \mathrm{C}\left\{{ }^{1} \mathrm{H}\right\}$ NMR (100.624 MHz, $\left.\mathrm{CD}_{2} \mathrm{Cl}_{2}, 293 \mathrm{~K}\right): \delta=168.1(\mathrm{~s}$, C8), 166.6 (s, $\left.J_{\mathrm{C}-\mathrm{Pt}}=710.1, \mathrm{C} 1\right), 150.3(\mathrm{~s}, \mathrm{C}), 141.7$ (s, C7), 139.2 (s, $\left.{ }^{2} J_{\mathrm{C}-\mathrm{Pt}}=66.7, \mathrm{C} 2\right)$, $132.1\left(\mathrm{~s},{ }^{3} J_{\mathrm{C}-\mathrm{Pt}}=36.1, \mathrm{C} 3\right), 125.4(\mathrm{~s}, \mathrm{C} 4), 125.1\left(\mathrm{~s},{ }^{3} J_{\mathrm{C}-\mathrm{Pt}}=24.7, \mathrm{C} 5\right), 116.1\left(\mathrm{~s},{ }^{4} J_{\mathrm{C}-\mathrm{Pt}}=\right.$ 30.7, C6), 58.8 (s, C $\equiv \mathrm{N}), 30.9$ (s, C-Me ${ }_{3}$ ) ppm. ${ }^{19} \mathrm{~F} \mathrm{NMR} \mathrm{(376.489} \mathrm{MHz,} \mathrm{CD}_{2} \mathrm{Cl}_{2}$ ): $\delta=-$ $70.0\left(\mathrm{~d}, J_{\mathrm{F}-\mathrm{P}}=716.1 \mathrm{~Hz}\right) \mathrm{ppm} .{ }^{31} \mathrm{P} \mathrm{NMR}\left(161.992 \mathrm{MHz}, \mathrm{CD}_{2} \mathrm{Cl}_{2}\right.$ ): $\delta=-144.1$ (sept, $J_{\mathrm{P}-\mathrm{F}}$ $=716.1 \mathrm{~Hz}) \mathrm{ppm} .{ }^{195} \mathrm{Pt}\left\{{ }^{1} \mathrm{H}\right\} \mathrm{NMR}\left(85.679 \mathrm{MHz}, \mathrm{CD}_{2} \mathrm{Cl}_{2}\right): \delta=-3795$ (s) (293K) ppm. Mass spectra MALDI+ DIT: $m / z=711 \quad\left[\mathrm{Pt}\left(\mathrm{C}_{17} \mathrm{H}_{11} \mathrm{~N}\right)\left(\mathrm{C}_{5} \mathrm{H}_{9} \mathrm{~N}\right) \mathrm{Tl}\right]^{+}, \quad 655$ $\left[\mathrm{Pt}\left(\mathrm{C}_{17} \mathrm{H}_{11} \mathrm{~N}\right)(\mathrm{NCH}) \mathrm{Tl}\right]^{+}, 508\left[\mathrm{Pt}\left(\mathrm{C}_{17} \mathrm{H}_{11} \mathrm{~N}\right)\left(\mathrm{C}_{5} \mathrm{H}_{9} \mathrm{~N}\right) \mathrm{H}\right]^{+}, 452\left[\mathrm{Pt}\left(\mathrm{C}_{17} \mathrm{H}_{11} \mathrm{~N}\right)(\mathrm{NC}) \mathrm{H}\right]^{+}$.

X-ray structure determinations. Crystal data and other details of the structure analyses are presented in Table 5. Suitable crystals for X-ray diffraction studies were obtained by slow diffusion of $n$-hexane into concentrated solutions of the complexes in $3 \mathrm{~mL}$ of $\mathrm{Me}_{2} \mathrm{CO}(\mathbf{1})$ or $\mathrm{CH}_{2} \mathrm{Cl}_{2}(\mathbf{3}, \mathbf{4})$. Crystals were mounted at the end of quartz fibres. The radiation used in all cases was graphite monochromated $\mathrm{MoK} \alpha_{\alpha}(\lambda=0.71073 \AA)$. Xray intensity data were collected on an Oxford Diffraction Xcalibur diffractometer. The diffraction frames were integrated and corrected from absorption by using the CrysAlis RED program. ${ }^{127}$ The structures were solved by Patterson and Fourier methods and refined by full-matrix least squares on $F^{2}$ with SHELXL-97. ${ }^{128}$ All non-hydrogen atoms were assigned anisotropic displacement parameters and refined without positional constraints, except as noted below. All hydrogen atoms were constrained to idealized 
geometries and assigned isotropic displacement parameters equal to 1.2 times the $U_{\text {iso }}$ values of their attached parent atoms (1.5 times for the methyl hydrogen atoms). For $\mathbf{1} \cdot 0.5 \mathrm{Me}_{2} \mathrm{CO}$, the acetone solvent molecule is disordered over two positions which were refined with the same occupancy. In the structure of $\mathbf{3}$, the axial fluorine atoms of the $\mathrm{PF}_{6}$ anion are disordered over two positions which were refined with the same occupancy. In the structure of $\mathbf{4}$, the fluorine atoms of one of the $\mathrm{PF}_{6}$ anions are badly disordered over three sets of positions, which were refined with partial occupancy 0.5/0.3/0.2. A common set of anisotropic thermal parameters was used for the equivalent fluorine atoms of each set. One of the $n$-hexane moieties was refined with partial occupancy 0.5 and their C-C distances constrained to reasonable values. A common set of anisotropic thermal parameters was used were used for all the $\mathrm{C}$ atoms of this molecule. Another $n$-hexane unit was disordered in such a way that the $\gamma$ carbon atom lies on an inversion centre, and thus the external $\alpha$ methyl carbon atom is disordered over two positions (0.5/0.5). A common set of anisotropic thermal parameters was used were used for all the $C$ atoms of this molecule. Restrains in the geometry of the $\mathrm{PF}_{6}{ }^{-}$anion were used. Full-matrix least-squares refinement of these models against $F^{2}$ converged to final residual indices given in Table 5.

Computational details. Density functional calculations were performed using the M06 ${ }^{129}$ hybrid functional under the Gaussian 09 package. ${ }^{130}$ The SDD pseudopotential and associated basis set ${ }^{131}$ was used for the platinum and thallium atoms and the 6$31 \mathrm{G}(\mathrm{d})^{132,133}$ basis set was used for all other atoms. Geometry optimisations were performed in the gas phase without symmetry restrictions, using initial coordinates derived from X-ray data. Atomic coordinates (x, y, z) for the optimized structures are shown in the Tables S2-S4 (see Supplementary Information). The time-dependent density-functional (TD-DFT) calculations were also carried out using the Gaussian 09 package. Mulliken population, Natural Bond Orbital (NBO) ${ }^{134}$ and Mayer bond order ${ }^{135}$ analyses were carried out using the Gaussian 09 package for interpretation purposes. Molekel $^{136}$ and ChemissianLab ${ }^{137}$ program packages were used for analysis and graphic representation of molecular structures and orbitals. 


\section{Acknowledgments.}

This work was supported by the Spanish MICINN (DGPTC/FEDER) (Project CTQ2008-06669-C02-01/BQU) and MINECO (CTQ2012-35251), and the Gobierno de Aragón (Grupo Consolidado E21: Química Inorgánica y de los Compuestos Organometálicos). The authors thank the Centro de Supercomputación de Galicia (CESGA) for generous allocation of computational resources. 


\section{References}

1 M.-E. Moret and P. Chen, J. Am. Chem. Soc., 2009, 131, 5675-5690.

2 J. Forniés, S. Ibáñez, A. Martín, M. Sanz, J. R. Berenguer, E. Lalinde, and J. Torroba, Organometallics, 2006, 25, 4331-4340.

3 J. Forniés, S. Ibáñez, A. Martín, B. Gil, E. Lalinde, and M. T. Moreno, Organometallics, 2004, 23, 3963-3975.

4 T. Yamaguchi, F. Yamazaki, and T. Ito, J. Am. Chem. Soc., 1999, 121, 74057406.

5 L. R. Falvello, J. Forniés, R. Garde, A. García, E. Lalinde, M. T. Moreno, A. Steiner, M. Tomás, and I. Usón, Inorg. Chem., 2006, 45, 2543-2552.

6 J. R. Berenguer, A. Díez, J. Fernández, J. Forniés, A. García, B. Gil, E. Lalinde, and M. T. Moreno, Inorg. Chem., 2008, 47, 7703-7716.

7 L. R. Falvello, J. Forniés, A. Martín, V. Sicilia, and P. Villarroya, Organometallics, 2002, 21, 4604-4610.

8 E. Alonso, J. Forniés, C. Fortuño, A. Martín, and A. G. Orpen, Organometallics, 2003, 22, 5011-5019.

9 F. D. Rochon and R. Melanson, Acta Cryst. Sect. C: Cryst. Struct. Commun., 1988, 44, 474-477.

10 J. Forniés, S. Fuertes, A. Martín, V. Sicilia, B. Gil, and E. Lalinde, Dalton Trans., 2009, 2224-2234.

11 J. M. Casas, J. Forniés, S. Fuertes, A. Martín, and V. Sicilia, Organometallics, 2007, 26, 1674-1685.

12 L. R. Falvello, J. Forniés, C. Fortuño, F. Durán, and A. Martín, Organometallics, 2002, 21, 2226-2234.

13 I. Ara, L. R. Falvello, J. Forniés, J. Gómez, E. Lalinde, R. I. Merino, and I. Usón, J. Organomet. Chem., 2002, 663, 284-288.

14 L. R. Falvello, J. Forniés, E. Lalinde, B. Menjón, M. A. Garcia Monforte, M. T. Moreno, and M. Tomás, Chem. Commun., 2007, 3838-3840.

15 T. Yamaguchi, F. Yamazaki, and T. Ito, J. Am. Chem. Soc., 2001, 123, 743-744.

16 J. Forniés, S. Ibáñez, E. Lalinde, A. Martín, M. T. Moreno, and A. C. Tsipis, Dalton Trans., 2012, 41, 3439-3451. 
17 S. Fuertes, C. H. Woodall, P. R. Raithby, and V. Sicilia, Organometallics, 2012, 31, 4228-4240.

18 P. Pyykkö, Chem. Rev., 1997, 97, 597-636.

19 P. Pyykkö, Angew. Chem. Int. Ed., 2004, 43, 4412-4456.

20 L. H. Gade, Angew. Chem. Int. Ed., 2001, 40, 3573-3575.

21 M. A. Carvajal, S. Álvarez, and J. J. Novoa, Chem, Eur. J., 2004, 10, $2117-$ 2132.

22 A. Díez, E. Lalinde, and M. T. Moreno, Coord. Chem. Rev., 2011, 255, 24262447.

23 P. T. Chou and Y. Chi, Chem. Eur. J., 2007, 13, 380-395.

24 M. W. Cooke and G. S. Hanan, Chem. Soc. Rev., 2007, 36, 1466-1476.

25 R. C. Evans, P. Douglas, and C. J. Wiscom, Coord. Chem. Rev., 2006, 250, 2093-2126.

26 E. Holder, B. M. W. Langeveld, and U. S. Schubert, Adv. Mater., 2005, 17, 1109-1121.

27 M. D. McClenaghan, N. D. Leydet, Y. Maubert, M. T. Indelli, and S. Campagna, Coord. Chem. Rev., 2005, 249, 1336-1350.

28 S. S. Sun and A. J. Lees, Coord. Chem. Rev., 2002, 230, 171-192.

29 W. Y. Wong, Comments Inorg. Chem., 2005, 26, 39-74.

30 M. H. V. Huynh, D. M. Dattelbaum, and T. J. Meyer, Coord. Chem. Rev., 2005, 249, 457-483.

31 A. Vogler and H. Kunkely, Top. Curr. Chem., 2001, 213, 143-182.

32 P. Thanasekaran, R. T. Liao, Y. H. Liu, T. Rajendran, S. Rajagopal, and K. L. Lu, Coord. Chem. Rev., 2005, 249, 1085-1110.

33 Coord. Chem. Rev., 2000, 208 (special issue), 1-371.

34 B. Ma, P. I. Djurovich, and M. E. Thompson, Coord. Chem. Rev., 2005, 249, 1501-1510.

35 S. Pérez, C. López, A. Caubet, R. Bosque, X. Solans, M. F. Bardía, A. Roig, and E. Molins, Organometallics, 2004, 23, 224-236.

36 E. J. Fernández, A. Laguna, and J. M. López de Luzuriaga, Dalton Trans., 2007, 1969-1981.

37 E. J. Fernández, A. Laguna, and J. M. López de Luzuriaga, Coord. Chem. Rev., 2005, 249, 1423-1433.

38 'Modern Supramolecular Gold Chemistry', ed. A. Laguna, Wiley-VCH, 2008. 
39 E. J. Fernández, J. M. López de Luzuriaga, M. Monge, M. A. Rodríguez, O. Crespo, M. C. Gimeno, A. Laguna, and P. G. Jones, Chem, Eur. J., 2000, 6, 636644.

40 V. W. W. Yam and E. C. C. Cheng, Chem. Soc. Rev., 2008, 37, 1806-1813.

41 O. Crespo, A. Laguna, E. J. Fernández, J. M. López de Luzuriaga, P. G. Jones, M. Teichert, M. Monge, P. Pyykkö, N. Runeberg, M. Schütz, and H. J. Werner, Inorg. Chem., 2000, 39, 4786-4792.

42 J. Forniés, V. Sicilia, J. M. Casas, A. Martín, J. A. López, C. Larraz, P. Borja, and C. Ovejero, Dalton Trans., 2011, 40, 2898-2912.

43 E. J. Fernández, A. Laguna, J. M. López de Luzuriaga, M. Montiel, M. E. Olmos, and J. Pérez, Organometallics, 2005, 24, 1631-1637.

44 I. Bytheway, C. S. Griffith, G. A. Koutsantonis, B. W. Skelton, and A. H. White, Eur. J. Inorg. Chem., 2007, 3240-3246.

45 M. A. Casado, J. J. Pérez-Torrente, J. A. López, M. A. Ciriano, F. J. Lahoz, and L. A. Oro, Inorg. Chem., 1999, 38, 2482-2488.

46 N. R. Halcovitch, C. M. Vogels, A. Decken, and S. A. Westcott, Can. J. Chem, 2009, 87, 139-145.

47 A. L. Balch, J. K. Nagle, M. M. Olmstead, and P. E. Reddy, J. Am. Chem. Soc., 1987, 109, 4123-4124.

48 A. L. Balch, F. Neve, and M. M. Olmstead, J. Am. Chem. Soc., 1991, 113, 29953001.

49 J. K. Nagle, A. L. Balch, and M. M. Olmstead, J. Am. Chem. Soc., 1988, 110, 319-321.

50 R. Usón, J. Forniés, M. Tomás, R. Garde, and R. Merino, Inorg. Chem., 1997, 36, 1383-1387.

51 A. L. Balch and S. P. Rowley, J. Am. Chem. Soc., 1990, 112, 6139-6140.

52 N. Oberbeckmann-Winter, P. Braunstein, and R. Welter, Organometallics, 2004, 23, 6311-6318.

53 J. Forniés, C. Fortuño, S. Ibáñez, and A. Martín, Inorg. Chem., 2008, 47, 59785987.

54 J. P. H. Charmant, J. Forniés, J. Gómez, E. Lalinde, R. I. Merino, M. T. Moreno, and A. G. Orpen, Organometallics, 2003, 22, 652-656.

55 F. Liu, W. Chen, and D. Wang, Chin. J. Struct. Chem., 2006, 25, 677-680. 
56 J. R. Berenguer, J. Fernández, E. Lalinde, and S. Sánchez, Chem. Commun, 2012, 48, 6384-6386.

57 H. B. Song, Z.-Z. Zhang, Z. Hui, C.-M. Che, and T. C. W. Mak, Inorg. Chem., 2002, 41, 3146-3154.

58 O. Renn, B. Lippert, and I. Mutikainen, Inorg. Chim. Acta, 1993, 208, 219-223.

59 W. Chen, F. Liu, D. X. Xu, K. Matsumoto, S. Kishi, and M. Kato, Inorg. Chem., 2006, 45, 5552-5560.

60 J. R. Stork, M. M. Olmstead, J. C. Fettinger, and A. L. Balch, Inorg. Chem., 2006, 45, 849-857.

61 J. Forniés, A. García, E. Lalinde, and M. T. Moreno, Inorg. Chem., 2008, 47, 3651-3660.

62 J. R. Stork, M. M. Olmstead, and A. L. Balch, J. Am. Chem. Soc., 2005, 127, 6512-6513.

63 A. Díez, J. Forniés, J. Gómez, E. Lalinde, A. Martín, M. T. Moreno, and S. Sánchez, Dalton Trans., 2007, 3653-3660.

64 A. Díez, J. Fernández, E. Lalinde, M. T. Moreno, and S. Sánchez, Inorg. Chem., 2010, 49, 11606-11618.

65 J. R. Berenguer, J. Forniés, B. Gil, and E. Lalinde, Chem. Eur. J., 2006, 12, 785795.

66 G. Wu and D. Wang, J. Cluster Sci., 2007, 18, 406-413.

67 V. J. Catalano and M. A. Malwitz, J. Am. Chem. Soc., 2004, 126, 6560-6561.

68 V. J. Catalano, B. L. Bennett, R. L. Yson, and B. C. Noll, J. Am. Chem. Soc., 2000, 122, 10056-10062.

69 V. J. Catalano, B. L. Bennett, S. Muratidis, and B. C. Noll, J. Am. Chem. Soc., 2000, 123, 173-174.

70 S. Jamali, M. M. Ashtiani, Z. Jamshidi, E. Lalinde, M. T. Moreno, H. Samouei, E. Escudero-Adán, and J. Benet-Buchholz, Inorg. Chem., 2013, 52, 1072910731.

71 M. P. Lanci, M. S. Remy, W. Kaminsky, J. M. Mayer, and M. S. Sanford, J. Am. Chem. Soc., 2009, 131, 15618-15620.

72 A. L. Balch, B. J. Davis, E. Y. Fung, and M. M. Olmstead, Inorg. Chim. Acta, 1993, 212, 149-156. 
73 E. Fernández, A. Garau, A. Laguna, T. Lasanta, V. Lippolis, J. M. López de Luzuriaga, M. Montiel, and M. E. Olmos, Organometallics, 2010, 29, 29512959.

74 E. J. Fernández, A. Laguna, J. M. López de Luzuriaga, M. E. Olmos, and J. Pérez, Dalton Trans., 2004, 1801-1806.

75 E. J. Fernández, J. M. López de Luzuriaga, M. Monge, M. Montiel, M. E. Olmos, and J. Pérez, Inorg. Chem., 2004, 43, 3573-3581.

76 E. J. Fernández, P. G. Jones, A. Laguna, J. M. López de Luzuriaga, M. Monge, M. Montiel, M. E. Olmos, and J. Pérez, Z. Naturforsch., B: Chem. Sci., 2004, 59, 1379-1386.

77 V. J. Catalano and M. A. Malwitz, J. Am. Chem. Soc., 2004, 126, 6560-6561.

78 E. J. Fernández, A. Laguna, J. M. López de Luzuriaga, M. Monge, M. Montiel, and M. E. Olmos, Inorg. Chem., 2007, 46, 2953-2955.

79 E. J. Fernández, A. Laguna, J. M. López de Luzuriaga, M. Montiel, M. E. Olmos, and J. Pérez, Inorg. Chim. Acta, 2005, 358, 4293-4300.

80 E. J. Fernández, A. Laguna, J. M. López de Luzuriaga, M. Montiel, M. E. Olmos, and J. Pérez, Organometallics, 2006, 25, 1689-1695.

81 E. J. Fernández, A. Laguna, T. Lasanta, J. M. López de Luzuriaga, M. Montiel, and M. E. Olmos, Organometallics, 2008, 27, 2971-2979.

82 E. J. Fernández, J. M. López de Luzuriaga, M. E. Olmos, and J. Pérez, Inorg. Chem., 2005, 44, 6012-6018.

83 M. Arca, T. Aroz, M. C. Gimeno, M. Kulcsar, A. Laguna, T. Lasanta, V. Lippolis, J. M. López de Luzuriaga, M. Monge, and M. E. Olmos, Eur. J. Inorg. Chem., 2011, 2288-2297.

84 A. Martín, U. Belío, S. Fuertes, and V. Sicilia, Eur. J. Inorg. Chem., 2013, 22312247.

85 C. Mealli, F. Pichierri, L. Randaccio, E. Zangrando, M. Krumm, D. Holtenrich, and B. Lippert, Inorg. Chem., 1995, 34, 3418-3424.

86 G. Aullón and S. Álvarez, Inorg. Chem., 1996, 3137-3144.

87 J. Forniés, J. Gómez, E. Lalinde, and M. T. Moreno, Inorg. Chem., 2001, 40, 5415-5419.

88 S. Fuertes, S. K. Brayshaw, P. R. Raithby, S. Schiffers, and M. R. Warren, Organometallics, 2012, 31, 105-119.

89 C. A. Hunter and J. K. M. Sanders, J. Am. Chem. Soc., 1990, 112, 5525-5534. 
90 C. A. Hunter, Chem. Soc. Rev., 1994, 101-109.

91 A. Díez, J. Forniés, A. García, E. Lalinde, and M. T. Moreno, Inorg. Chem., 2005, 44, 2443-2453.

92 W. Lu, M. C. W. Chan, N. Zhu, C. M. Che, C. Li, and Z. Hui, J. Am. Chem. Soc., 2004, 126, 7639-7651.

93 V. W. Yam, R. P. L. Tang, K. M. C. Wong, X. X. Lu, K. K. Cheung, and N. Zhu, Chem. Eur. J., 2002, 8, 4066-4076.

94 S. J. Farley, D. L. Rochester, A. L. Thompson, J. A. K. Howard, and J. A. Williams, Inorg. Chem., 2005, 44, 9690-9703.

95 M. Munakata, L. P. Wu, G. L. Ning, T. Kuroda-Sowa, M. Maekawa, Y. Suenaga, and N. Maeno, J. Am. Chem. Soc., 1999, 121, 4968-4976.

96 M. Munakata, L. P. Wu, T. Kuroda-Sowa, M. Maekawa, Y. Suenaga, G. L. Ning, and T. Kojima, J. Am. Chem. Soc., 1998, 120, 8610-8618.

97 M. Munakata, J. C. Zhong, T. Kuroda-Sowa, M. Maekawa, Y. Suenaga, M. Kasahara, and H. Konaka, Inorg. Chem., 2001, 40, 7087-7090.

98 M. Munakata, L. P. Wu, T. Kuroda-Sowa, M. Maekawa, Y. Suenaga, T. Ohta, and H. Konaka, Inorg. Chem., 2003, 42, 2553-2558.

99 U. Belío, S. Fuertes, and A. Martín, Inorg. Chem., 2013, 52, 5627-5629.

100 G. W. V. Cave, N. W. Alcock, and J. P. Rourke, Organometallics, 1999, 18, 1801-1803.

101 J. R. Berenguer, E. Lalinde, and J. Torroba, Inorg. Chem., 2007, 46, 9919-9930.

102 P. J. Lusby, P. Müller, S. J. Pike, and A. M. Z. Slawin, J. Am. Chem. Soc., 2009, 131, 16398-16400.

103 G. W. V. Cave, F. P. Fanizzi, R. J. Deeth, W. Errington, and J. P. Rourke, Organometallics, 2000, 19, 1355-1364.

104 W. Lu, M. C. W. Chan, K.-K. Cheung, and C.-M. Che, Organometallics, 2001, 20, 2477-2486.

105 O. Kristiansson, Eur. J. Inorg. Chem., 2002, 2355-2361.

106 L. M. Clarkson, W. Clegg, D. C. R. Hockless, N. C. Norman, and T. B. Marder, J. Chem. Soc., Dalton Trans., 1991, 2229-2239.

107 J. W. van Hal, L. B. Alemany, and K. H. Whitmire, Inorg. Chem., 1997, 36, 3152-3159. 
108 J. Forniés and A. Martín, in 'Platinate (II) Complexes as Building Blocks for Complexes with Pt-M (Donor-Acceptor) Bonds', ed. P. Braunstein, L. A. Oro, and P. R. Raithby, Weinheim, 1999.

109 S. Welsch, C. Lescop, R. Reau, and M. Scheer, Dalton Trans., 2009, 2683-2686.

110 Y. Sarazin, D. L. Hughes, N. Kaltsoyannis, J. A. Wright, and M. Bochmann, J. Am. Chem. Soc., 2007, 129, 881-894.

111 E. J. Fernández, A. Laguna, J. M. López-de-Luzuriaga, M. Monge, M. Montiel, and M. E. Olmos, Inorg. Chem., 2007, 46, 2953-2955.

112 Y. Sarazin, N. Kaltsoyannis, J. A. Wright, and M. Bochmann, Organometallics, 2007, 26, 1811-1815.

113 E. J. Fernández, A. Laguna, J. M. López-de-Luzuriaga, M. Elena Olmos, and J. Pérez, Chem. Commun., 2003, 1760-1761.

114 H. B. Mansaray, M. Kelly, D. Vidovic, and S. Aldridge, Chem. Eur. J., 2011, 17, 5381-5386.

115 J. C. Thomas and J. C. Peters, Inorg. Chem., 2003, 42, 5055-5073.

116 J. Vicente, R. V. Shenoy, E. Martínez-Viviente, and P. G. Jones, Inorg. Chem., 2011, 50, 7189-7194.

117 P. J. Schebler, C. G. Riordan, I. A. Guzei, and A. L. Rheingold, Inorg. Chem., 1998, 37, 4754-4755.

118 X. Li, H. Song, and C. Cui, Dalton Trans., 2009, 9728-9730.

119 K. Kunz, F. Blasberg, M. Bolte, H.-W. Lerner, and M. Wagner, Inorg. Chim. Acta, 2009, 362, 4372-4376.

120 J. R. Berenguer, E. Lalinde, M. T. Moreno, S. Sánchez, and J. Torroba, Inorg. Chem., 2012, 51, 11665-11679.

121 S. J. Berners-Price, L. Ronconi, and P. J. Sadler, Prog. Nucl. Magn. Reson. Spectrosc., 2006, 49, 65-98.

122 J. R. Berenguer, J. Fernández, B. Gil, E. Lalinde, and S. Sánchez, Inorg. Chem., 2010, 49, 4232-4244.

123 D. E. Janzen, L. F. Mehne, D. G. VanDerveer, and G. J. Grant, Inorg. Chem., 2005, 44, 8182-8184.

124 M. Maliarik, J. K. Nagle, A. Ilyukhin, E. Murashova, J. Mink, M. Skripkin, J. Glaser, M. Kovacs, and A. Horväth, Inorg. Chem., 2007, 46, 4642-4653.

125 S. C. F. Kui, S. S. Y. Chui, C. M. Che, and N. Zhu, J. Am. Chem. Soc., 2006, 128, 8297-8309. 
126 J. H. K. Yip, Suwarno, and J. J. Vittal, Inorg. Chem., 2000, 39, 3537-3543.

127 CysAlis RED, CCD camera data reduction program, Oxford Diffraction, Oxford, UK, 2004.

128 G. M. Sheldrick, Acta Cryst., 2008, A64, 112-122.

129 Y. Zhao and D. G. Truhlar, Theor. Chem. Acc., 2008, 120, 215-241.

130 M. J. Frisch, G. W. Trucks, H. B. Schlegel, G. E. Scuseria, M. A. Robb, J. R. Cheeseman, G. Scalmani, V. Barone, B. Mennucci, G. A. Petersson, H. Nakatsuji, M. Caricato, X. Li, H. P. Hratchian, A. F. Izmaylov, J. Bloino, G. Zheng, J. L. Sonnenberg, M. Hada, M. Ehara, K. Toyota, R. Fukuda, J. Hasegawa, M. Ishida, T. Nakajima, Y. Honda, O. Kitao, H. Nakai, T. Vreven, J. A. Montgomery, J. E. Peralta, F. Ogliaro, M. Bearpark, J. J. Heyd, E. Brothers, K. N. Kudin, V. N. Staroverov, R. Kobayashi, J. Normand, K. Raghavachari, A. Rendell, J. C. Burant, S. S. Iyengar, J. Tomasi, M. Cossi, N. Rega, J. M. Millam, M. Klene, J. E. Knox, J. B. Cross, V. Bakken, C. Adamo, J. Jaramillo, R. Gomperts, R. E. Stratmann, O. Yazyev, A. J. Austin, R. Cammi, C. Pomelli, J. W. Ochterski, R. L. Martin, K. Morokuma, V. G. Zakrzewski, G. A. Voth, P. Salvador, J. J. Dannenberg, S. Dapprich, A. D. Daniels, O. Farkas, J. B. Foresman, J. V. Ortiz, J. Cioslowski, and D. J. Fox, Gaussian 09 (Revision B.01), Wallingford CT, 2010.

131 D. Andrae, U. Haussermann, M. Dolg, H. Stoll, and H. Preuss, Theoretica Chimica Acta, 1990, 77, 123-141.

132 R. Ditchfield, W. J. Herhe, and J. A. Pople, J. Chem. Phys., 1971, 54, 724-728.

133 P. C. Hariharan and J. A. Pople, Theoretica Chimica Acta, 1973, 28, 213-222.

134 A. E. Reed, L. A. Curtiss, and F. Weinhold, Chem. Rev., 1988, 88, 899-926.

135 I. Mayer, Chem. Phys. Lett., 1983, 97, 270-274.

136 U. Varetto, MOLEKEL 5.4, Swiss National Supercomputing Centre: Lugano, Switzerland, 2009.

137 Chemissian, a computer program to analyse and visualise quantum-chemical calculations. Available from http://www.chemissian.com'. 
Table 1. Selected bond lengths $(\AA)$ and angles $\left(^{\circ}\right)$ for $[\mathrm{Pt}(\mathrm{CNC})($ tht $)] \cdot 0.5 \mathrm{Me}_{2} \mathrm{CO}$ $\left(\mathbf{1} \cdot 0.5 \mathrm{Me}_{2} \mathrm{CO}\right)$

\begin{tabular}{lrlr} 
Pt-N & $1.983(2)$ & $\mathrm{Pt}-\mathrm{C}(13)$ & $2.062(3)$ \\
$\mathrm{Pt}-\mathrm{C}(1)$ & $2.067(3)$ & $\mathrm{Pt}-\mathrm{S}$ & $2.2473(6)$ \\
& & & \\
$\mathrm{N}-\mathrm{Pt}-\mathrm{C}(13)$ & $80.69(10)$ & $\mathrm{N}-\mathrm{Pt}-\mathrm{C}(1)$ & $80.60(10)$ \\
$\mathrm{C}(13)-\mathrm{Pt}-\mathrm{C}(1)$ & $160.70(10)$ & $\mathrm{N}-\mathrm{Pt}-\mathrm{S}$ & $174.77(7)$ \\
$\mathrm{C}(13)-\mathrm{Pt}-\mathrm{S}$ & $95.32(7)$ & $\mathrm{C}(1)-\mathrm{Pt}-\mathrm{S}$ & $103.62(7)$ \\
\hline
\end{tabular}

Table 2. Selected bond lengths $(\AA)$ and angles $\left(^{\circ}\right)$ for $\left[\{\mathrm{Pt}(\mathrm{CNC})(\text { tht })\}_{3} \mathrm{Tl}\right]\left(\mathrm{PF}_{6}\right)(3)$

\begin{tabular}{lrlr} 
Pt-N & $1.996(13)$ & $\mathrm{Pt}-\mathrm{C}(1)$ & $2.072(10)$ \\
Pt-S & $2.262(4)$ & $\mathrm{Pt}-\mathrm{Tl}$ & $2.9088(5)$ \\
& & & \\
N-Pt-C(1) & $80.8(3)$ & $\mathrm{C}(1) \# 1-\mathrm{Pt}-\mathrm{C}(1)$ & $159.9(6)$ \\
N-Pt-S & $169.1(3)$ & $\mathrm{C}(1)-\mathrm{Pt}-\mathrm{S}$ & $99.8(3)$ \\
N-Pt-Tl & $100.2(3)$ & $\mathrm{C}(1)-\mathrm{Pt}-\mathrm{Tl}$ & $87.8(3)$ \\
S-Pt-Tl & $90.68(10)$ & $\mathrm{Pt} 2-\mathrm{Tl}-\mathrm{Pt}$ & 120.0 \\
\hline
\end{tabular}

Symmetry transformations used to generate equivalent atoms: $\# 1 \mathrm{x}, \mathrm{y},-\mathrm{z}+3 / 2 ; \# 2-\mathrm{y}+1, \mathrm{x}-$ $\mathrm{y}+1, \mathrm{z}$ 
Table 3. Selected bond lengths $(\AA)$ and angles $\left(^{\circ}\right)$ for $\left[\left\{\mathrm{PtTl}\left(\mathrm{C}_{17} \mathrm{H}_{11} \mathrm{~N}\right)\left(\mathrm{CN}^{t} \mathrm{Bu}\right)\right\}_{3}\right]\left(\mathrm{PF}_{6}\right)_{3} \cdot 1.5 n-\mathrm{C}_{6} \mathrm{H}_{14}\left(4 \cdot 1.5 n-\mathrm{C}_{6} \mathrm{H}_{14}\right)$.

\begin{tabular}{|c|c|c|c|}
\hline $\operatorname{Pt}(1)-C(18)$ & $1.913(7)$ & $\operatorname{Pt}(1)-\mathrm{N}(1)$ & $1.988(5)$ \\
\hline $\operatorname{Pt}(1)-C(1)$ & $2.055(6)$ & $\operatorname{Pt}(1)-C(13)$ & $2.075(7)$ \\
\hline $\operatorname{Pt}(1)-\mathrm{Tl}(1)$ & 3.0143(3) & $\operatorname{Pt}(2)-C(40)$ & $1.905(7)$ \\
\hline $\mathrm{Pt}(2)-\mathrm{N}(3)$ & $2.002(5)$ & $\mathrm{Pt}(2)-\mathrm{C}(35)$ & $2.070(7)$ \\
\hline $\operatorname{Pt}(2)-C(23)$ & $2.071(7)$ & $\operatorname{Pt}(2)-\mathrm{Tl}(2)$ & 3.0488(3) \\
\hline $\operatorname{Pt}(3)-C(62)$ & $1.893(7)$ & $\operatorname{Pt}(3)-\mathrm{N}(5)$ & $1.997(5)$ \\
\hline $\operatorname{Pt}(3)-C(57)$ & $2.062(7)$ & $\mathrm{Pt}(3)-\mathrm{C}(45)$ & $2.078(6)$ \\
\hline $\mathrm{Pt}(3)-\mathrm{Tl}(3)$ & $3.0460(3)$ & & \\
\hline $\mathrm{C}(18)-\mathrm{Pt}(1)-\mathrm{N}(1)$ & 177.1(3) & $\mathrm{C}(18)-\mathrm{Pt}(1)-\mathrm{C}(1)$ & $96.8(3)$ \\
\hline $\mathrm{N}(1)-\mathrm{Pt}(1)-\mathrm{C}(1)$ & $80.9(2)$ & $\mathrm{C}(18)-\mathrm{Pt}(1)-\mathrm{C}(13)$ & 102.2(3) \\
\hline $\mathrm{N}(1)-\mathrm{Pt}(1)-\mathrm{C}(13)$ & $80.1(2)$ & $\mathrm{C}(1)-\mathrm{Pt}(1)-\mathrm{C}(13)$ & 160.8(3) \\
\hline $\mathrm{C}(40)-\mathrm{Pt}(2)-\mathrm{N}(3)$ & 177.2(3) & $\mathrm{C}(40)-\mathrm{Pt}(2)-\mathrm{C}(35)$ & 101.7(3) \\
\hline $\mathrm{N}(3)-\mathrm{Pt}(2)-\mathrm{C}(35)$ & $80.7(2)$ & $\mathrm{C}(40)-\operatorname{Pt}(2)-\mathrm{C}(23)$ & $96.5(3)$ \\
\hline$N(3)-P t(2)-C(23)$ & $81.1(2)$ & $\mathrm{C}(35)-\mathrm{Pt}(2)-\mathrm{C}(23)$ & 161.8(3) \\
\hline $\mathrm{C}(40)-\mathrm{Pt}(2)-\mathrm{Tl}(2)$ & 81.65(19) & $\mathrm{C}(62)-\mathrm{Pt}(3)-\mathrm{N}(5)$ & $178.3(2)$ \\
\hline $\mathrm{C}(62)-\mathrm{Pt}(3)-\mathrm{C}(57)$ & 99.3(3) & $\mathrm{N}(5)-\mathrm{Pt}(3)-\mathrm{C}(57)$ & $80.6(2)$ \\
\hline $\mathrm{C}(62)-\mathrm{Pt}(3)-\mathrm{C}(45)$ & $99.4(3)$ & N(5)-Pt(3)-C(45) & $80.6(2)$ \\
\hline$C(57)-P t(3)-C(45)$ & 161.2(3) & $\mathrm{C}(62)-\mathrm{Pt}(3)-\mathrm{Tl}(3)$ & $85.54(19)$ \\
\hline N(5)-Pt(3)-Tl(3) & $96.07(15)$ & $\mathrm{C}(57)-\mathrm{Pt}(3)-\mathrm{Tl}(3)$ & $112.87(16)$ \\
\hline $\mathrm{C}(45)-\mathrm{Pt}(3)-\mathrm{Tl}(3)$ & 70.67(18) & & \\
\hline
\end{tabular}


Table 4. Emission Data for complexes 1-4

\begin{tabular}{|c|c|c|c|}
\hline Comp. & Media $(\mathrm{T}[\mathrm{K}])$ & $\lambda_{\mathrm{em}}\left(\lambda_{\mathrm{ex}}\right)[\mathrm{nm}]$ & $\tau[\mu s]$ \\
\hline \multirow[t]{4}{*}{1} & Solid (298) & $561,585,666_{\max }(441)$ & $\mathrm{a}$ \\
\hline & Solid (77) & $680_{\max }(441)$ & $2.7(680)$ \\
\hline & $\mathrm{CH}_{2} \mathrm{Cl}_{2}(77)^{b}$ & $508_{\max }, 547,591,637(460)$ & 23.2 (508), 4 (637) \\
\hline & $\mathrm{CH}_{2} \mathrm{Cl}_{2}(77)^{c}$ & 507 $\max , 546,586(405)$ & 22.6 (507), 21.0 (546), 18.6 (586) \\
\hline \multirow[t]{4}{*}{2} & Solid (298) & $538_{\text {sh }}, 565,600_{\max }(439)$ & $\mathrm{a}$ \\
\hline & Solid (77) & 637 (439) & 2.7 (637) \\
\hline & $\mathrm{CH}_{2} \mathrm{Cl}_{2}(77)^{b}$ & $635(420)$ & 2.7 (635) \\
\hline & $\mathrm{CH}_{2} \mathrm{Cl}_{2}(77)^{c}$ & $476,514,560$ sh, 620 $\max (336)$ & 39.5 (476) \\
\hline \multirow[t]{4}{*}{3} & Solid (298) & $604(441)$ & $\mathrm{a}$ \\
\hline & Solid (77) & $601(401)$ & $1.4(601)$ \\
\hline & $\mathrm{CH}_{2} \mathrm{Cl}_{2}(77)^{b}$ & $610(407)$ & $3.1(610)$ \\
\hline & $\mathrm{CH}_{2} \mathrm{Cl}_{2}(77)^{c}$ & $509,546,610_{\max }(340-460)$ & 30.9 (509); 5.0 (610) \\
\hline \multirow[t]{6}{*}{4} & Solid (298) & $735(550)$ & $\mathrm{a}$ \\
\hline & Solid (77) & 735 (508) & $2.5(735)$ \\
\hline & $\mathrm{CH}_{2} \mathrm{Cl}_{2}(77)^{b}$ & $615,690_{\text {sh }}(<440)$ & 3.8 (615) \\
\hline & & $615,700(450-500)$ & \\
\hline & & $720(>500)$ & $3.4(720)$ \\
\hline & $\mathrm{CH}_{2} \mathrm{Cl}_{2}(77)^{c}$ & $476,514,558,612_{\max }(336)$ & $46.7(476)$ \\
\hline
\end{tabular}

${ }^{a}$ Too weak to be measured. ${ }^{b} 10^{-3} \mathrm{M} \cdot{ }^{c} 10^{-5} \mathrm{M}$. 
Table 5. Crystal data and structure refinement for complexes $[\mathrm{Pt}(\mathrm{CNC})($ tht $\left.)] \cdot 0.5 \mathrm{Me}_{2} \mathrm{CO}\left(\mathbf{1} \cdot 0.5 \mathrm{Me}_{2} \mathrm{CO}\right),\left[\{\mathrm{Pt}(\mathrm{CNC})(\mathrm{tht})\}_{3} \mathrm{Tl}\right](\mathrm{PF})_{6}\right)(\mathbf{3})$ and $\left[\left\{\mathrm{PtTl}\left(\mathrm{C}_{17} \mathrm{H}_{11} \mathrm{~N}\right)\left(\mathrm{CN}^{t} \mathrm{Bu}\right)\right\}_{3}\right]\left(\mathrm{PF}_{6}\right)_{3} \cdot 1.5 n-\mathrm{C}_{6} \mathrm{H}_{14}\left(4 \cdot 1.5 n-\mathrm{C}_{6} \mathrm{H}_{14}\right)$.

\begin{tabular}{llll}
\hline & $\mathbf{1} \cdot 0.5 \mathrm{Me}_{2} \mathrm{CO}$ & $\mathbf{3}$ & $\mathbf{4} \cdot 1.5 n-\mathrm{C}_{6} \mathrm{H}_{14}$ \\
\hline CCDC number & 966072 & 966073 & 987896 \\
Formula & $\mathrm{C}_{21} \mathrm{H}_{19} \mathrm{NPtS} \cdot 0.5 \mathrm{Me}_{2} \mathrm{CO}$ & $\mathrm{C}_{63} \mathrm{H}_{57} \mathrm{~F}_{6} \mathrm{~N}_{3} \mathrm{PPt}_{3} \mathrm{~S}_{3} \mathrm{Tl}$ & $\mathrm{C}_{66} \mathrm{H}_{60} \mathrm{~F}_{18} \mathrm{~N}_{6} \mathrm{P}_{3} \mathrm{Pt}_{3} \mathrm{Tl}_{3} \cdot 1.5 n-\mathrm{C}_{6} \mathrm{H}_{14}$ \\
$M$ & 541.56 & 1886.91 & 2699.75 \\
Crystal system & monoclinic & hexagonal & monoclinic \\
Space group & $C 2 / c$ & $P-62 c$ & $C 2 / c$ \\
$a / \AA$ & $42.5046(14)$ & $15.6681(8)$ & $31.2557(7)$ \\
$b / \AA$ & $9.9891(3)$ & $15.6681(8)$ & $22.8837(3)$ \\
$c / \AA$ & $9.0748(3)$ & $13.2867(8)$ & $24.1734(3)$ \\
$\beta /{ }^{\circ}$ & $101.875(3)$ & 90 & $107.275(2)$ \\
$V / \AA^{3}$ & $3770.6(2)$ & $2824.8(3)$ & $16510.0(5)$ \\
$T / \mathrm{K}$ & $100(1)$ & $100(1)$ & $100(1)$ \\
$Z$ & 8 & 2 & 8 \\
$M(\mathrm{Mo}-\mathrm{K \alpha}) / \mathrm{mm}^{-1}$ & 7.562 & 10.453 & 11.042 \\
$D_{c} / \mathrm{g} \mathrm{cm}$ & & 2.218 & 2.172 \\
$F(000)$ & 1.908 & 1776 & 10056 \\
$2 \theta \mathrm{range}^{-0}$ & 2096 & $8.5-52.0$ & $8.3-51.0$
\end{tabular}




$\begin{array}{llll}\text { No. of data collected } & 23519 & 14729 & 83127 \\ \text { No. of unique data } & 4560 & 1939 & 15322 \\ R_{\text {int }} & 0.0398 & 0.0364 & 0.0421 \\ R_{1}, w R_{2}^{a}(I>2 \sigma(I)) & 0.0182,0.0456 & 0.0331,0.0889 & 0.0293,0.0686 \\ R_{1}, w R_{2}^{a}(\text { all data }) & 0.0188,0.0460 & 0.0341,0.0984 & 0.0373,0.0725 \\ \text { GOF }\left(F^{2}\right)^{b} & 1.071 & 1.043 & 1.074 \\ \text { Absolute structure parameter } & - & 0.02(2) & -\end{array}$

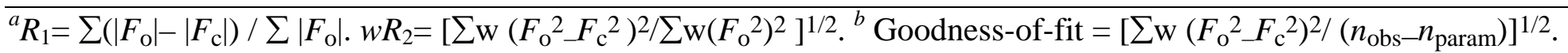




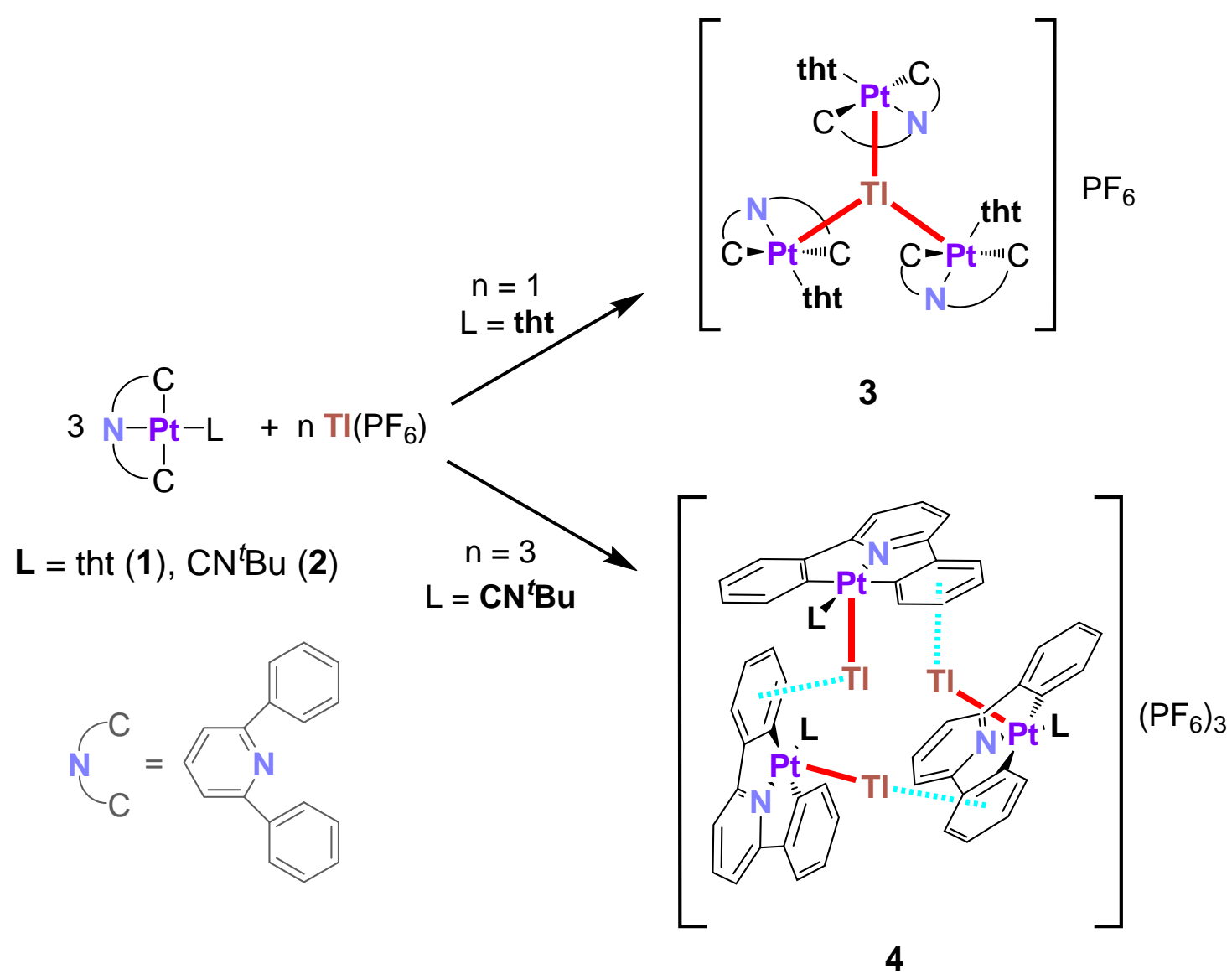

Scheme 1. Syntheses of complexes $\mathbf{3}$ and $\mathbf{4}$.

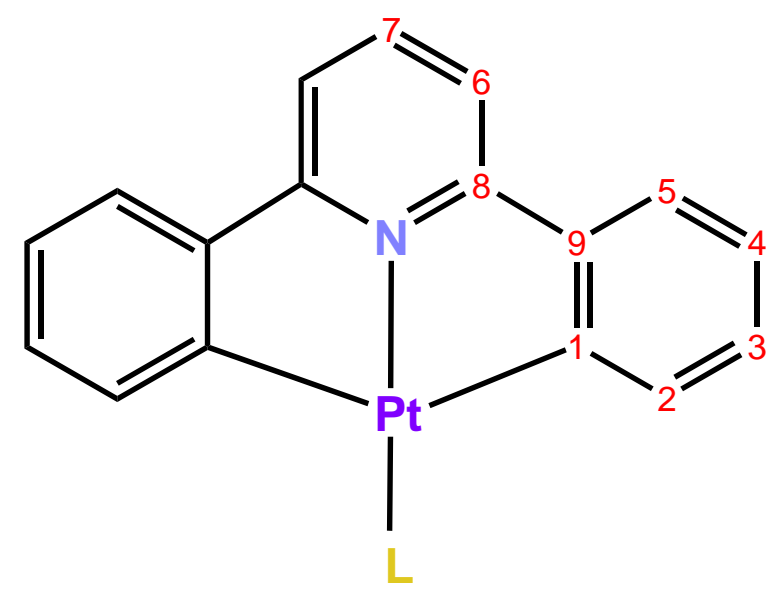

Scheme 2. H numbering scheme for the ligand C,N,C-2,6- $\mathrm{NC}_{5} \mathrm{H}_{3}\left(\mathrm{C}_{6} \mathrm{H}_{4}-2\right)_{2}$ 


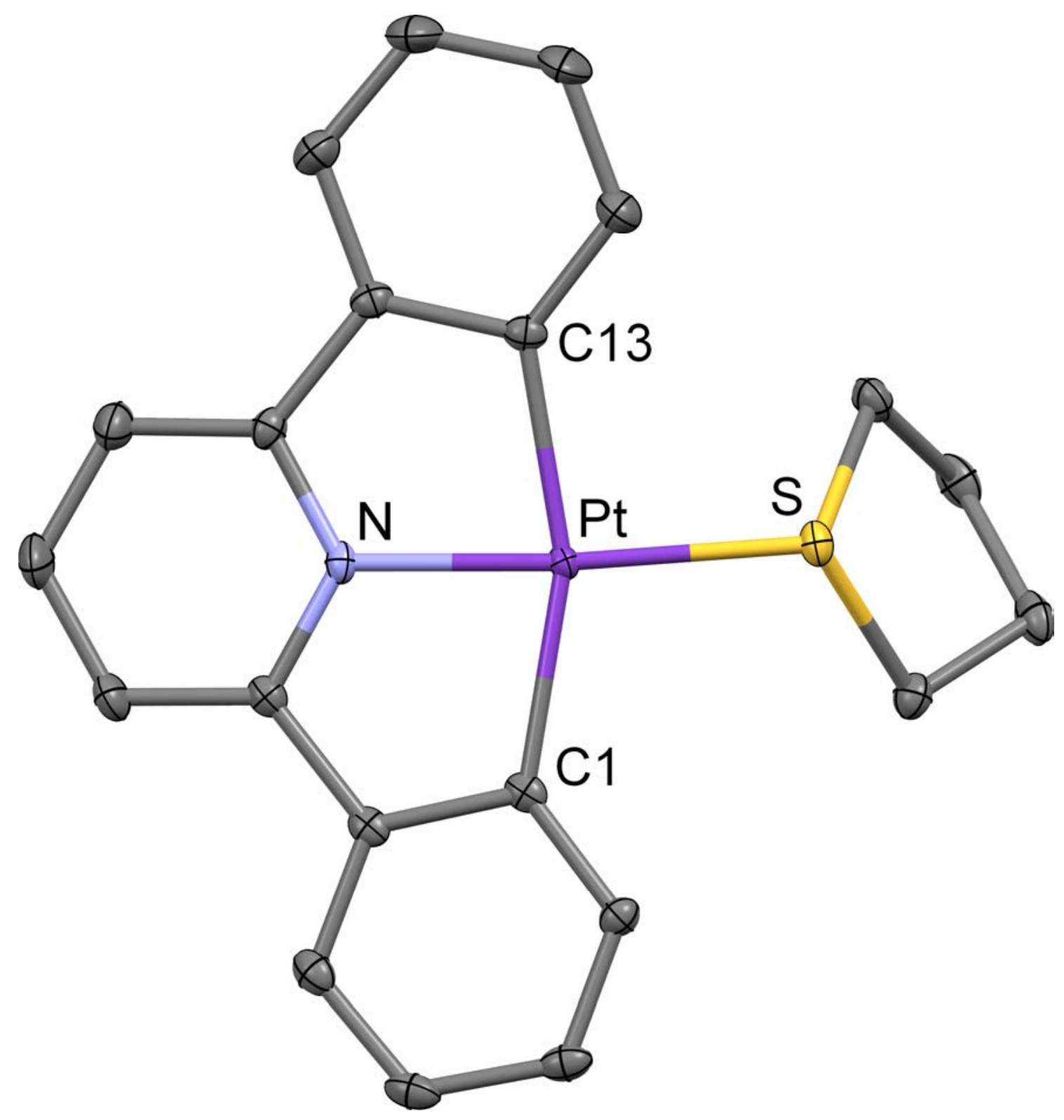

Figure 1. Molecular structure of complex 1. Ellipsoids are drawn at the $50 \%$ probability level. Hydrogen atoms have been omitted for clarity. 


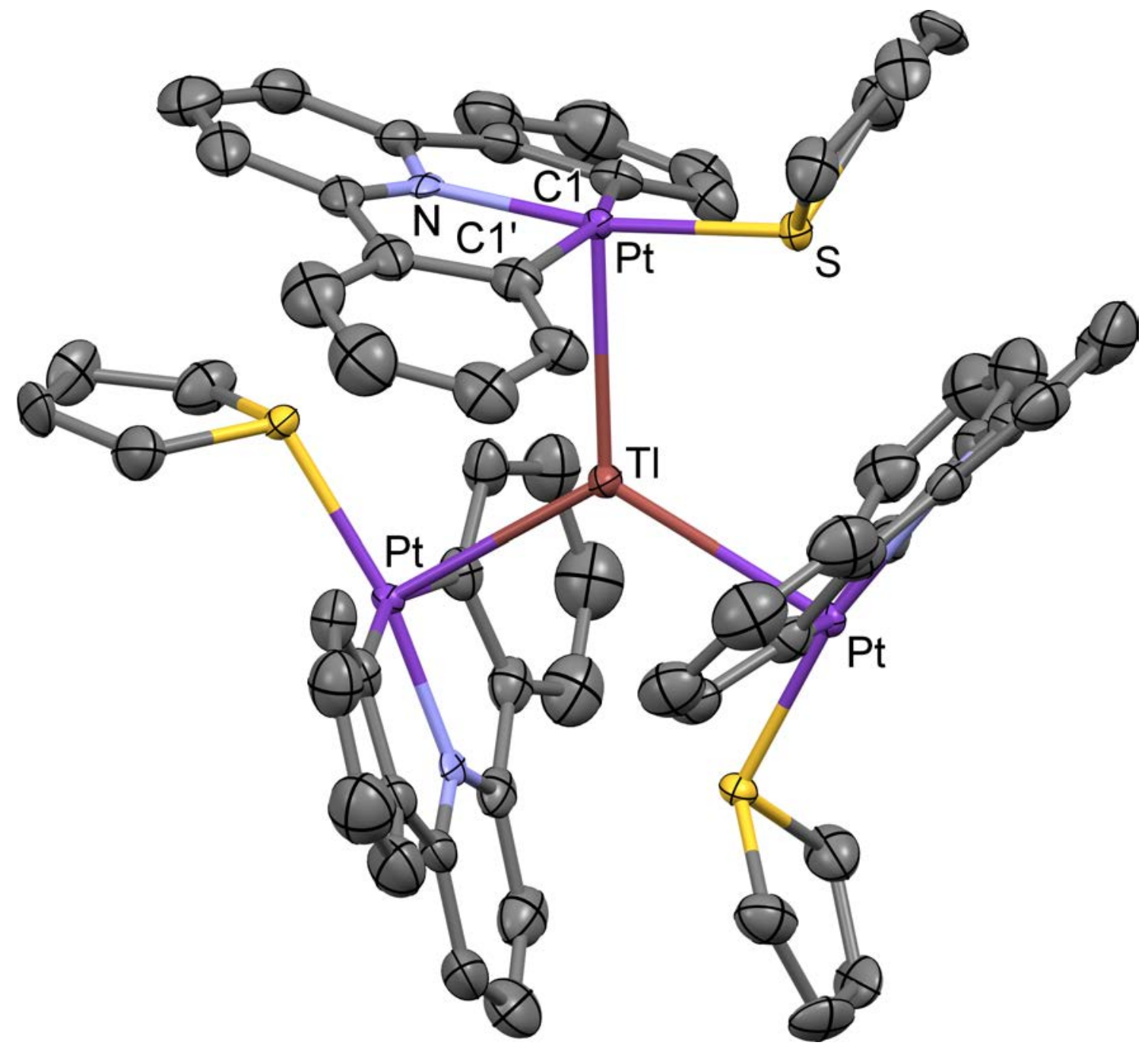

Figure 2. Molecular structure of the cation of complex 3. Ellipsoids are drawn at the $50 \%$ probability level. Hydrogen atoms have been omitted for clarity. 


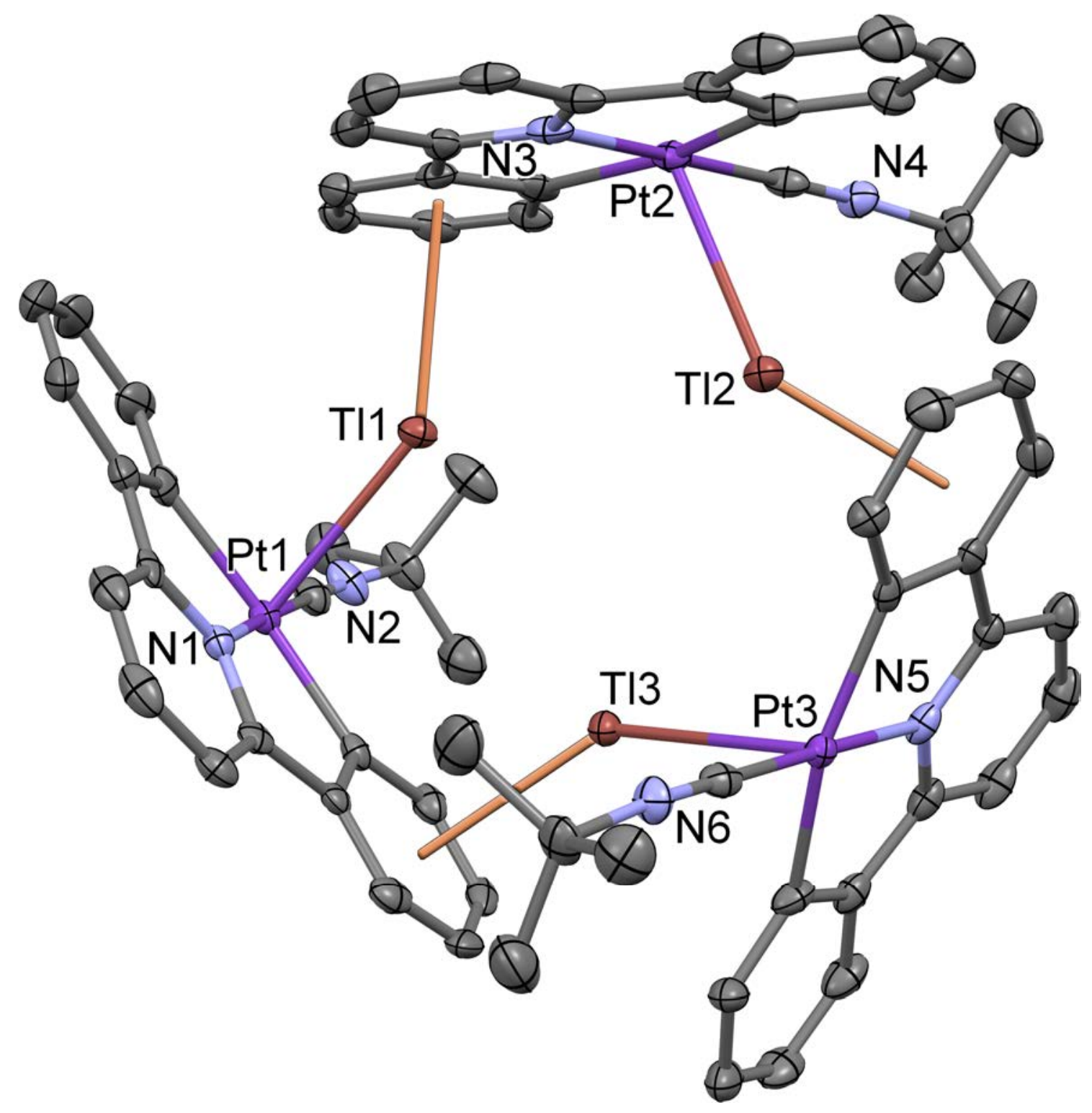

Figure 3. Molecular structure of the cation of complex 4. Ellipsoids are drawn at the $50 \%$ probability level. Hydrogen atoms have been omitted for clarity. 


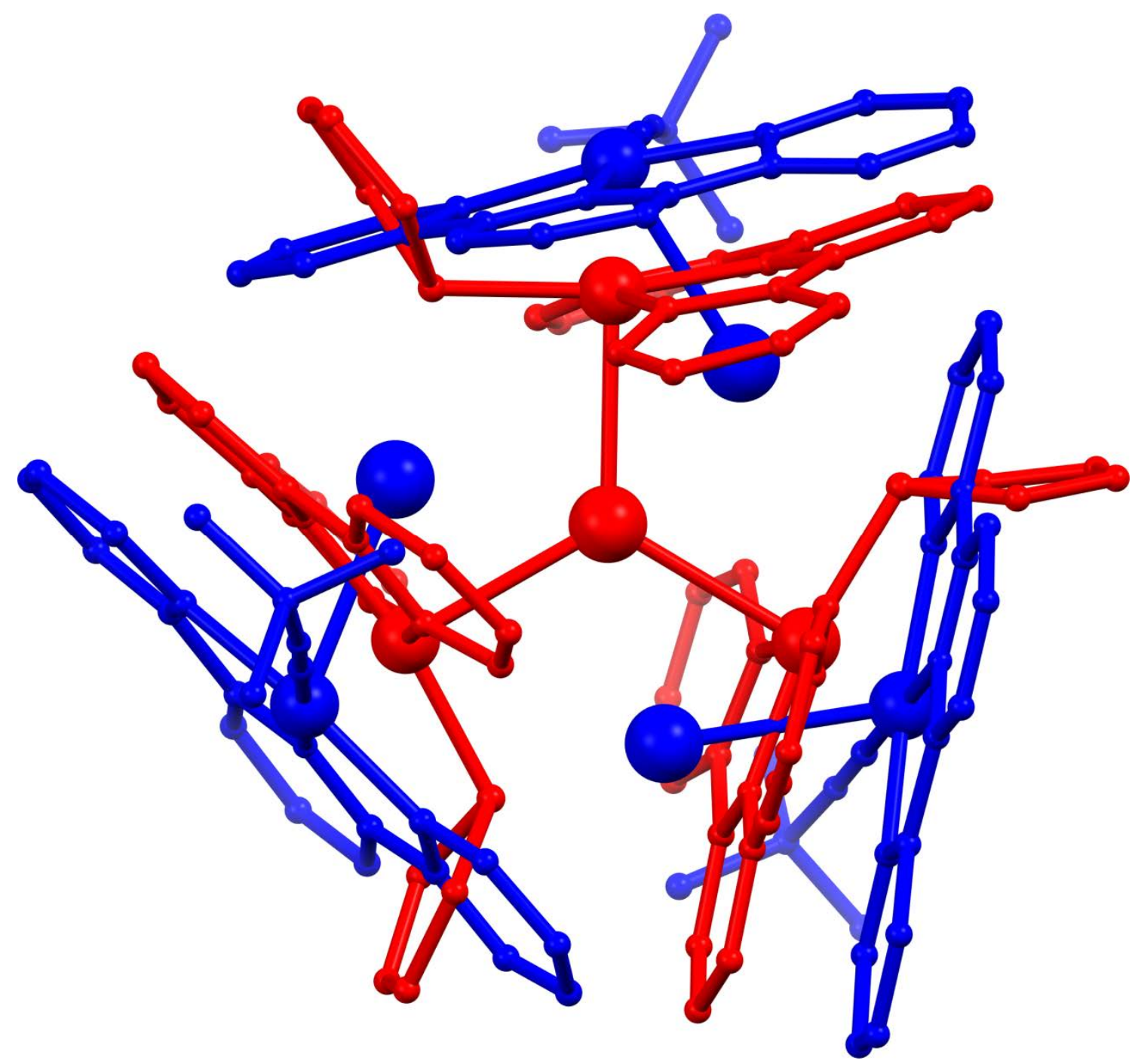

Figure 4. Superposition of the molecular structures of the cations of complexes 3 (red) and 4 (blue). 
II-

$213 \mathrm{~K}$

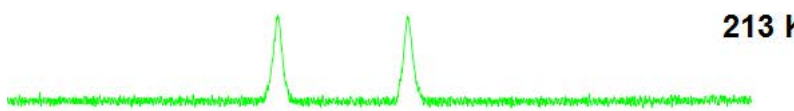

$243 \mathrm{~K}$
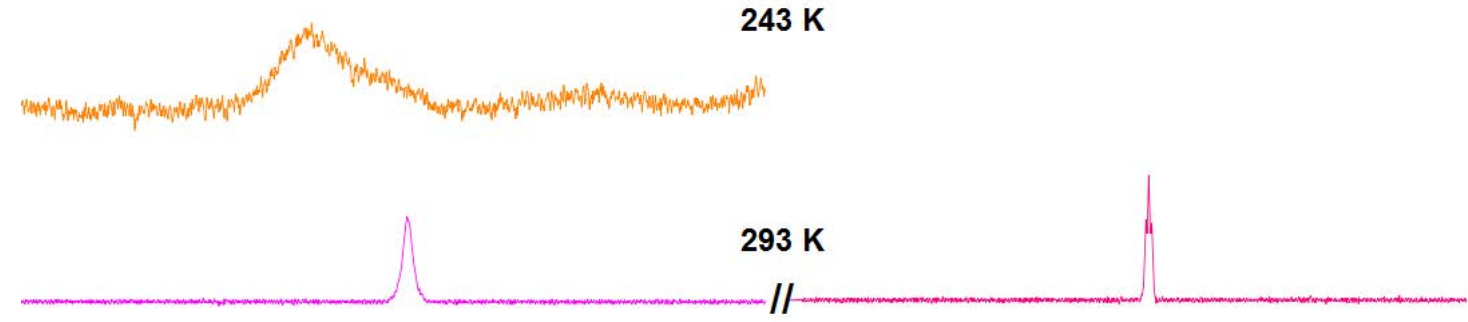

(a)

(b)

\begin{tabular}{cccccccccc}
\hline & & & & & & & & & [ppm] \\
\hline-2900 & -3000 & -3100 & -3200 & -3300 & -3400 & -3600 & -3800 & -4000 & -4200
\end{tabular}

Figure 5. ${ }^{195} \mathrm{Pt}$ NMR spectra of compounds: $\mathbf{3}+\mathrm{TlPF}_{6}$ exc. (a) and $\mathbf{1}$ (b) in $\mathrm{CD}_{2} \mathrm{Cl}_{2}$ at variable temperature. 


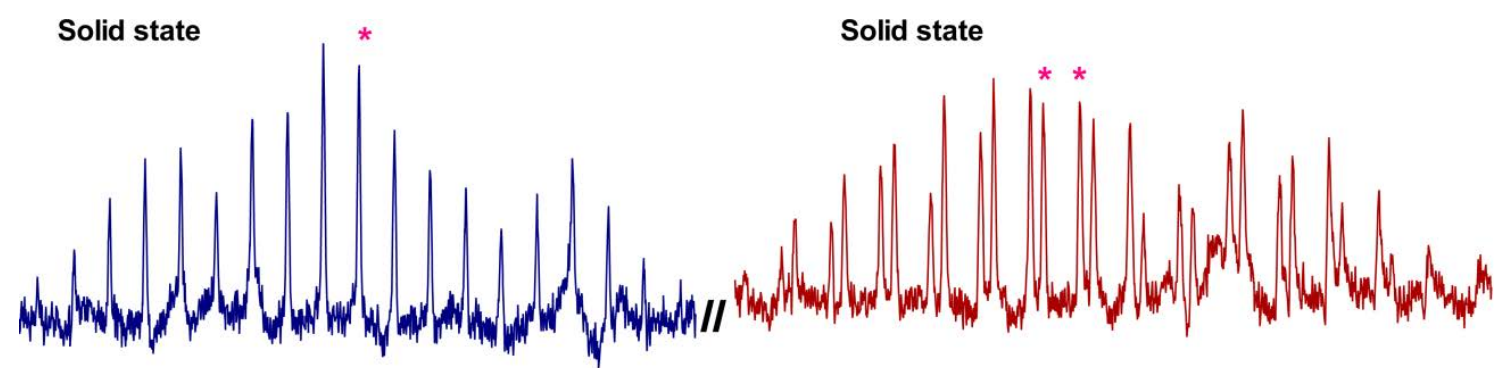

$\mathrm{CD}_{2} \mathrm{Cl}_{2}$ Solution 193K

$\mathrm{CD}_{2} \mathrm{Cl}_{2}$ Solution 193K
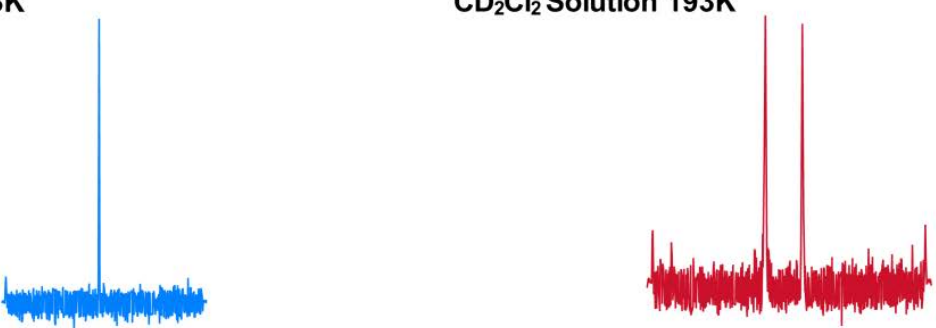

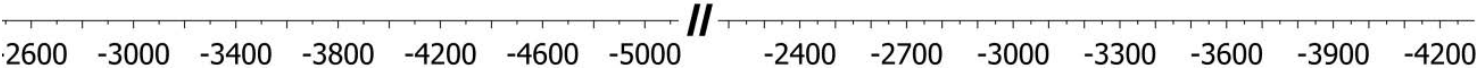

Figure 6. Comparison between the solid state (above) and solution (below) ${ }^{195} \mathrm{Pt}$ NMR spectra of compounds 1 (blue) and 3 (red). Solid state ${ }^{195} \mathrm{Pt}$ NMR spectra are registered at spinning speeds of $12 \mathrm{kHz}$. 
$263 \mathrm{~K}$
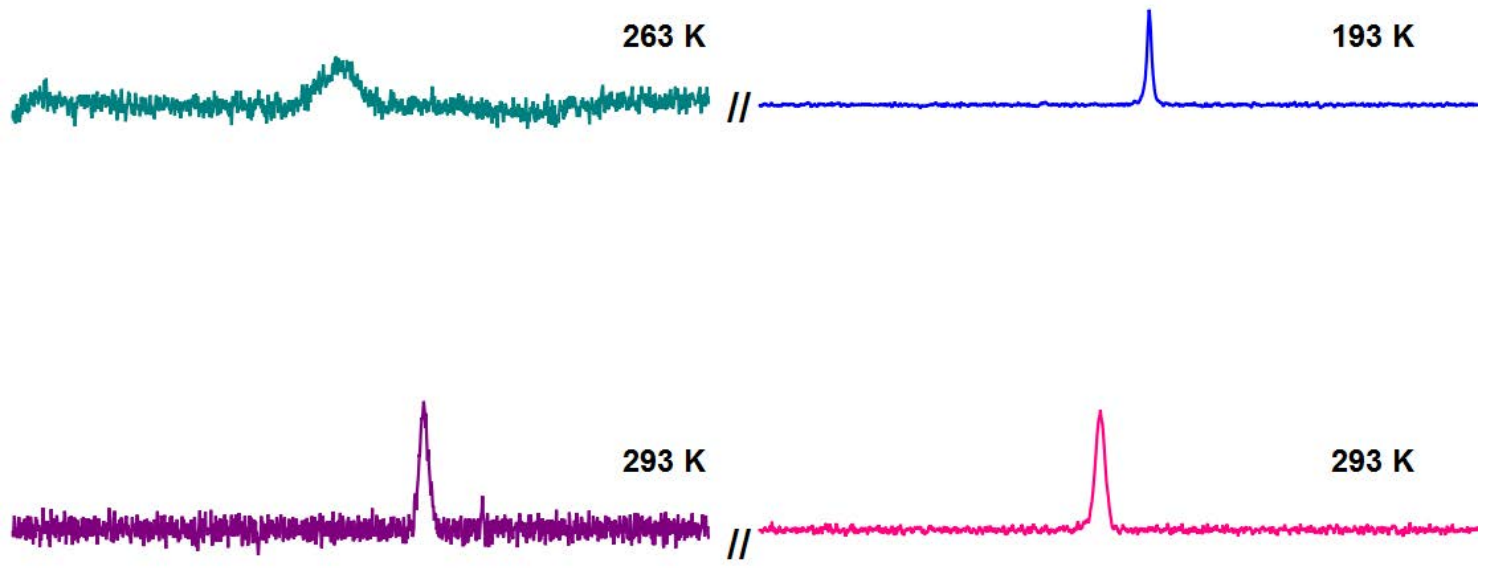

(a)

(b)

$-3400-3500-3600-3700-3800-3900-4000$

Figure 7. ${ }^{195} \mathrm{Pt}$ NMR spectra of compounds: $\mathbf{4}+\mathrm{TlPF}_{6}$ exc. (a) and 2 (b) in $\mathrm{CD}_{2} \mathrm{Cl}_{2}$ at variable temperature. 


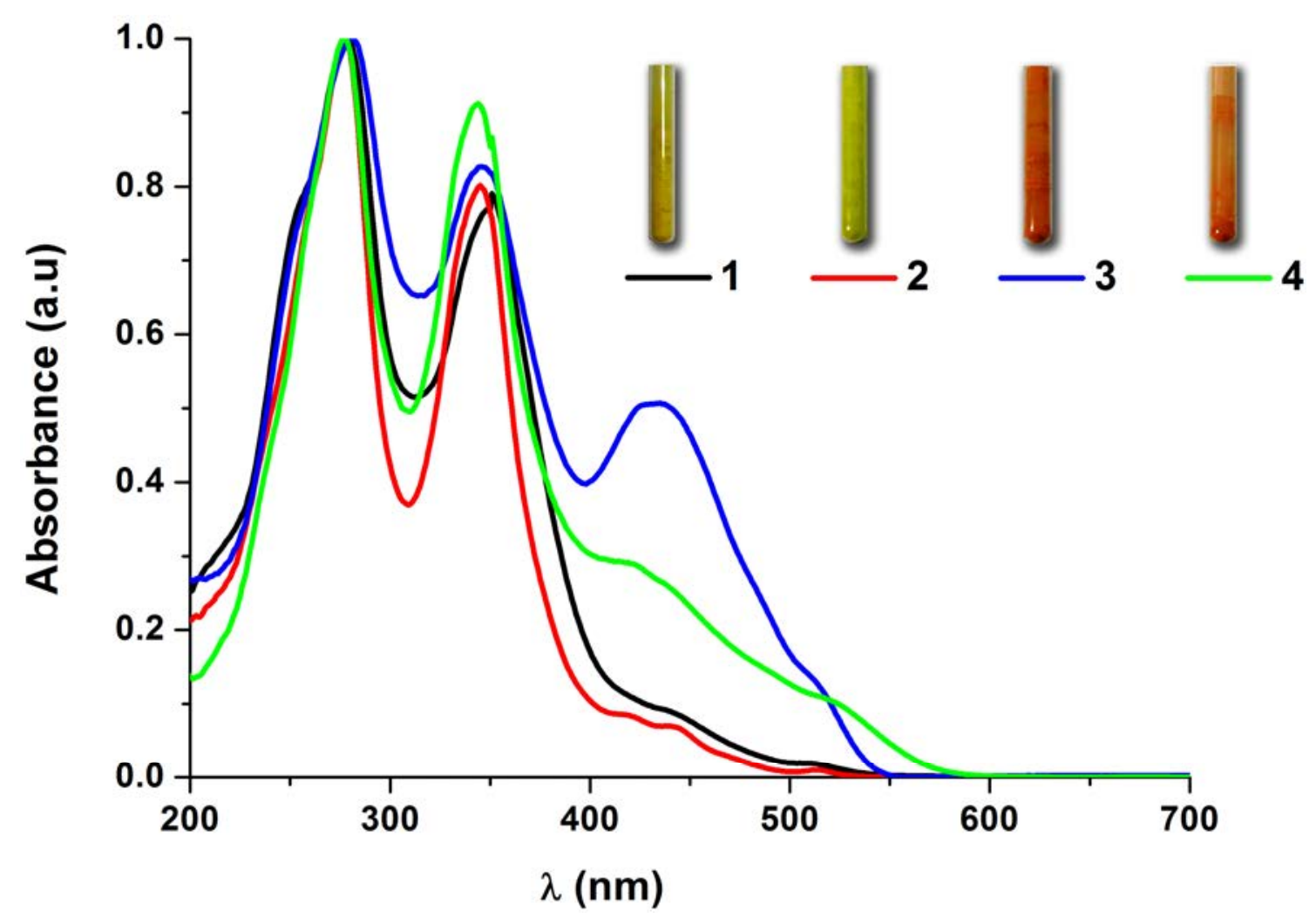

Figure 8. Normalized Diffuse Reflectance spectra of 1-4 in solid state at room temperature. 


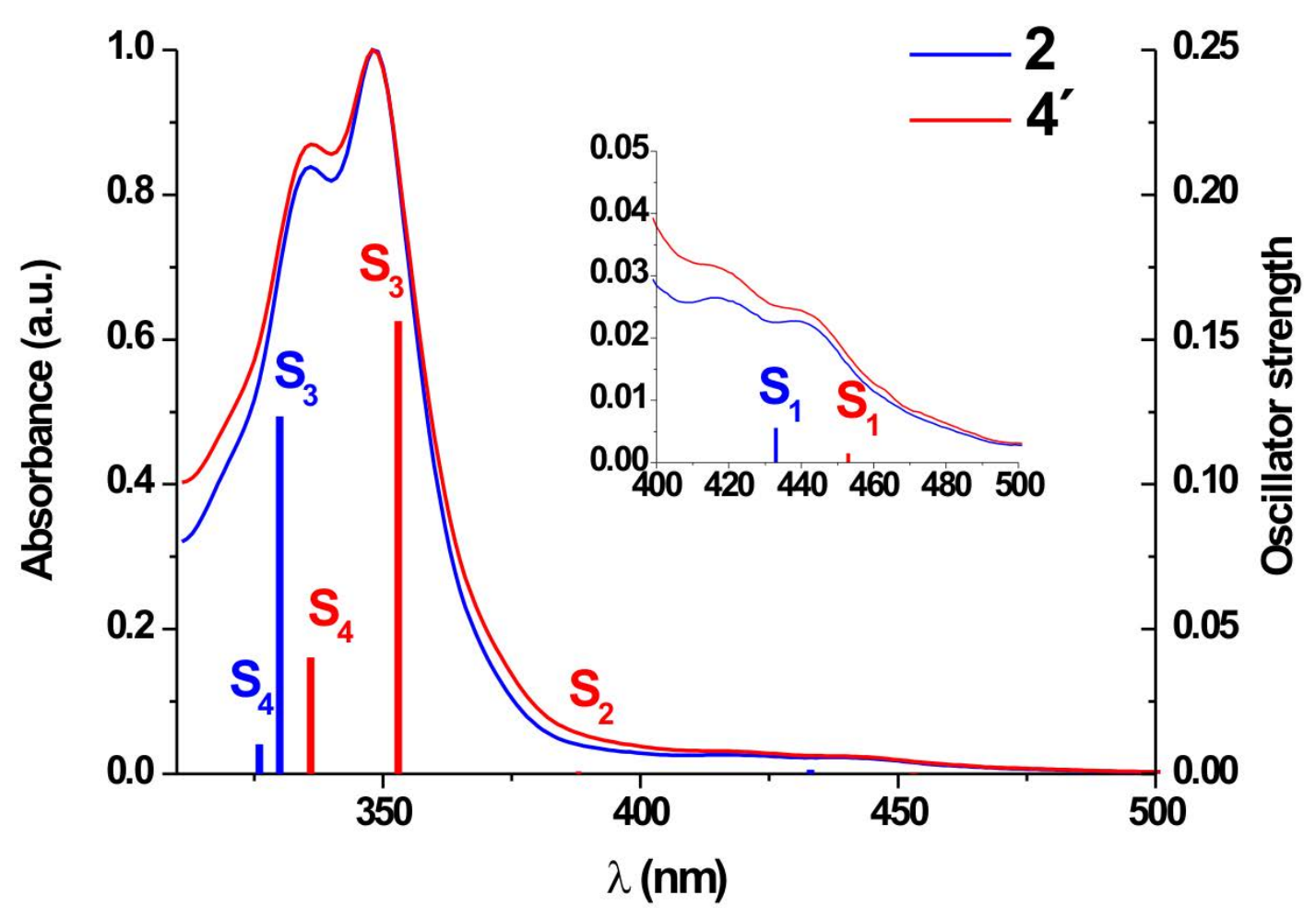

(a)

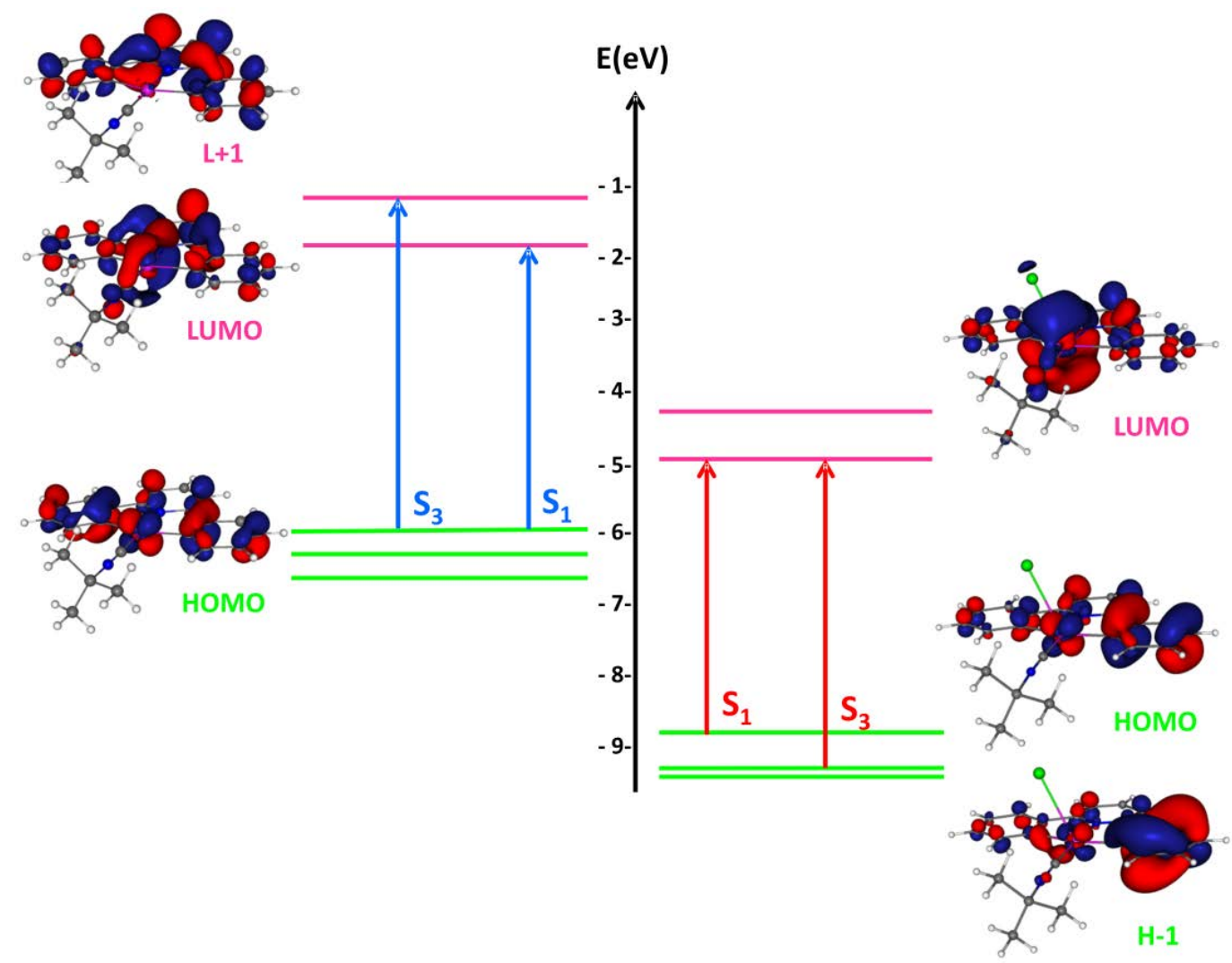

(b)

Figure 9. a) Normalized UV-vis spectra in dichloromethane $\left(10^{-4} \mathrm{M}\right)$ at $298 \mathrm{~K}$ and calculated transitions of $\mathbf{2}$ and 4' (bars). b) Most important transitions ( $\geq 85 \%$ ) involved in lower energy excited calculated states (S1 and S3). 


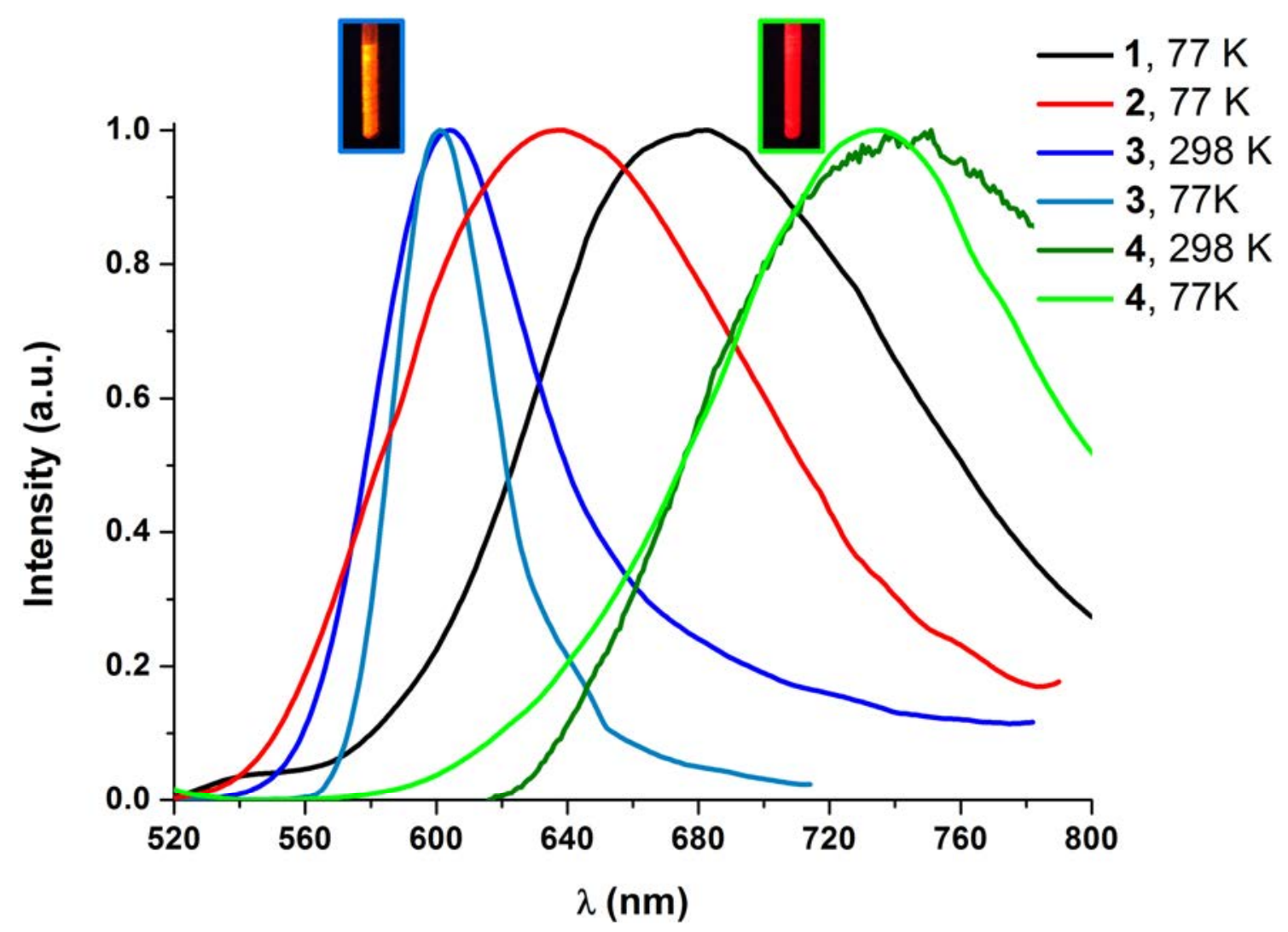

Figure 10. Normalized solid state emission spectra. Pictures of solid samples of $\mathbf{3}$ (left) and 4 (right) at $77 \mathrm{~K}$ under the UV light. 


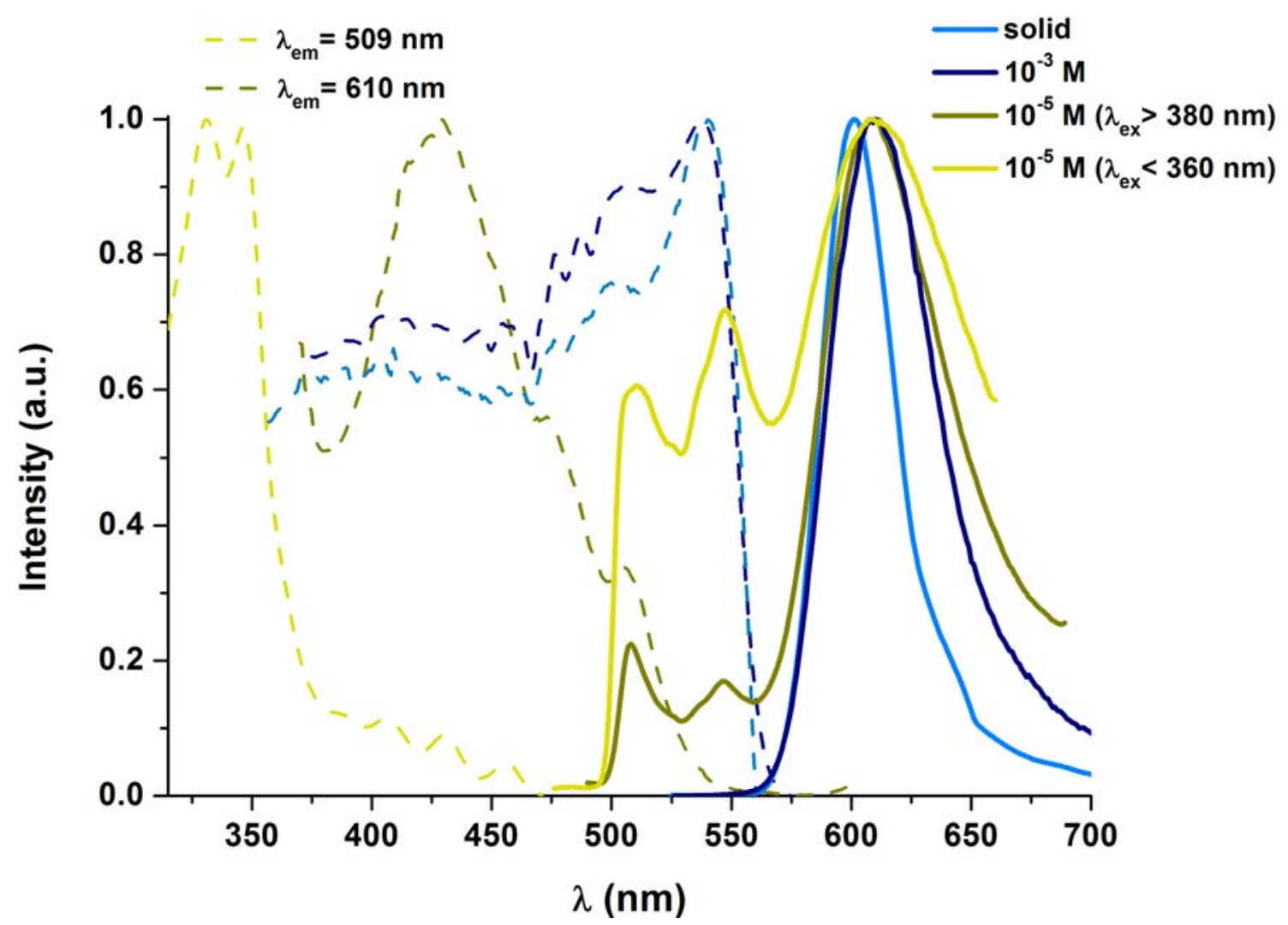

Figure 11. Normalized excitation (dashed line) and emission (solid line) spectra of 3.

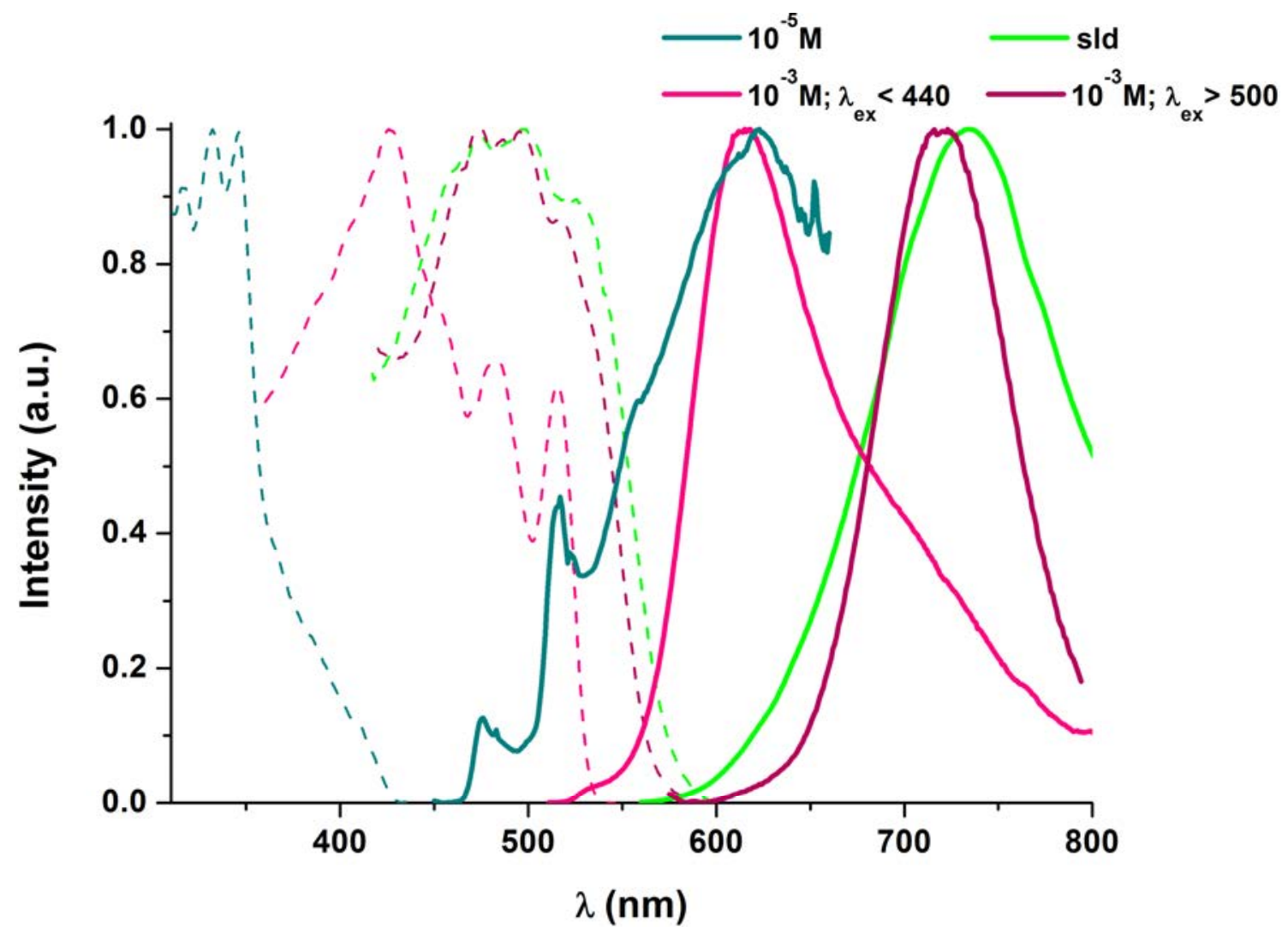

Figure 12. Normalized excitation (dashed line) and emission (solid line) spectra of 4. 
$\mathrm{Pt}(\mathrm{II})-\mathrm{Tl}(\mathrm{I})$ clusters with new triangular geometry have been prepared and characterized. Pt-Tl distances are among the shortest reported so far, indicating a fairly strong metal-metal bond that remains in solution (NMR).

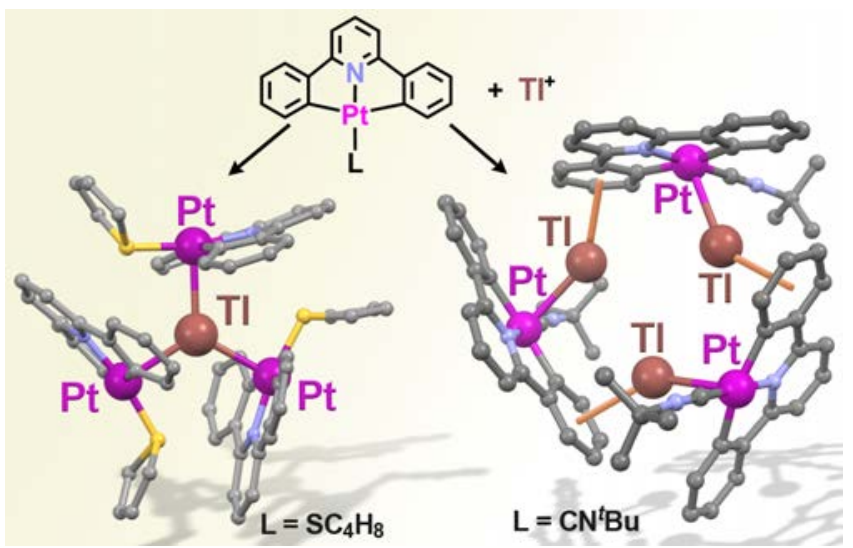

